\title{
Bulletin of Volcanology
}

\section{Silicic conduits as supersized tuffisites: Clastogenic influences on shifting eruption styles at Cordón Caulle volcano (Chile) \\ --Manuscript Draft--}

\begin{tabular}{|c|c|}
\hline Manuscript Number: & BUVO-D-20-00088R1 \\
\hline Full Title: & $\begin{array}{l}\text { Silicic conduits as supersized tuffisites: Clastogenic influences on shifting eruption } \\
\text { styles at Cordón Caulle volcano (Chile) }\end{array}$ \\
\hline Article Type: & Research Article \\
\hline Corresponding Author: & $\begin{array}{l}\text { C lan Schipper } \\
\text { Victoria University of Wellington } \\
\text { NEW ZEALAND }\end{array}$ \\
\hline \multicolumn{2}{|c|}{$\begin{array}{l}\text { Corresponding Author Secondary } \\
\text { Information: }\end{array}$} \\
\hline \multirow[t]{14}{*}{ Order of Authors: } & C lan Schipper \\
\hline & Jonathan M. Castro \\
\hline & Ben M. Kennedy \\
\hline & Hugh Tuffen \\
\hline & Jack Whattam \\
\hline & Fabian B. Wadsworth \\
\hline & Rebecca Paisley \\
\hline & Rebecca H. Fitzgerald \\
\hline & Emma Rhodes \\
\hline & Lauren N. Schaefer \\
\hline & Paul A. Ashwell \\
\hline & Pablo Forte \\
\hline & Gilles Seropian \\
\hline & Brent V. Alloway \\
\hline \multicolumn{2}{|l|}{ Funding Information: } \\
\hline Abstract: & $\begin{array}{l}\text { Understanding the processes that drive explosive-effusive transitions during large } \\
\text { silicic eruptions is crucial to hazard mitigation. Conduit models usually treat magma } \\
\text { ascent and degassing as a gradual, unidirectional progression from bubble nucleation } \\
\text { through to magmatic fragmentation. However, there is growing evidence for the } \\
\text { importance of bi-directional clastogenic processes that sinter fragmented materials into } \\
\text { coherent clastogenic magmas. Bombs that were ejected immediately before the first } \\
\text { emergence of lava in the } 2011-2012 \text { eruption at Cordón Caulle volcano (Chile) are } \\
\text { texturally heterogeneous composite assemblages of welded pyroclastic material. } \\
\text { Although diverse in density and appearance, SEM and X-Ray tomographic analysis } \\
\text { show them all to have been formed by multi-generational viscous sintering of fine ash. } \\
\text { Sintering created discrete clasts ranging from obsidian to pumice and formed a } \\
\text { pervasive clast-supporting matrix that assembled these clasts into a conduit-sealing } \\
\text { plug. An evaluation of sintering timescales reveals texturally disparate bomb } \\
\text { components to represent only minutes of difference in residence time within the } \\
\text { conduit. Permeability modeling indicates that the plug was an effective conduit seal, } \\
\text { with outgassing potential - even from high-porosity regions - being limited by the } \\
\text { inability of gas to flow across tendrils of densely sintered inter-clast matrix. Contrary to } \\
\text { traditional perspectives, declining expressions of explosivity at the surface need not be } \\
\text { preceded or accompanied by a decline in fragmentation efficiency. Instead, they result } \\
\text { from tips in balance between the opposing processes of fragmentation and sintering } \\
\text { that occur in countless cycles within volcanic conduits. These processes may be }\end{array}$ \\
\hline
\end{tabular}




\begin{tabular}{|c|c|}
\hline & $\begin{array}{l}\text { particularly enhanced at silicic fissure volcanoes, which have laterally extensive } \\
\text { subsurface plumbing systems that require complex magma ascent pathways. The } \\
\text { textures investigated here reveal the processes occurring within silicic fissures to be } \\
\text { phenomenologically identical to those that have been inferred to occur in tuffisite veins: } \\
\text { silicic conduits are essentially supersized examples of edifice-penetrating tuffisite } \\
\text { veins. }\end{array}$ \\
\hline Response to Reviewers: & Please see attached document: Schipper et al. Revisions.docx \\
\hline Author Comments: & $\begin{array}{l}\text { Dear Bulletin of Volcanology editorial board, } \\
\text { We are pleased to submit for your consideration the manuscript: Silicic conduits as } \\
\text { supersized tuffisites: Clastogenic influences on shifting eruption styles at Cordón } \\
\text { Caulle volcano (Chile) } \\
\text { This manuscript is the product of several years of analysis on eruption products from } \\
\text { the } 2011-2012 \text { Cordón Caulle eruption. It contains data and interpretations that link } \\
\text { transitions in eruption style to clastogenic processes occurring in the conduit. These } \\
\text { are major current topics in volcanology, and we believe this work will be of wide } \\
\text { interest to the readership of the Bulletin of Volcanology. } \\
\text { We respectfully ask that Dr. Y. Moussallam not be assigned as the handling editor for } \\
\text { this submission, due to conflicts of interest with the lead author. } \\
\text { We thank you for considering our work for publication. } \\
\text { With regards, } \\
\text { Dr. C. lan Schipper, on behalf of all co-authors }\end{array}$ \\
\hline
\end{tabular}




\title{
1 Silicic conduits as supersized tuffisites: Clastogenic influences on
} 2 shifting eruption styles at Cordón Caulle volcano (Chile)

\section{3}

\author{
C. Ian Schipper ${ }^{1 *}$, Jonathan M. Castro ${ }^{2}$, Ben M. Kennedy ${ }^{3}$, Hugh Tuffen ${ }^{4}$, Jack Whattam ${ }^{1}$, Fabian B. \\ Wadsworth $^{5}$, Rebecca Paisley ${ }^{6}$, Rebecca H. Fitzgerald ${ }^{3}$, Emma Rhodes ${ }^{3,7}$, Lauren N. Schaefer ${ }^{3,8}$, Paul A. \\ Ashwell $^{3,9}$, Pablo Forte ${ }^{2,10}$, Gilles Seropian ${ }^{3}$, Brent V. Alloway ${ }^{11,12}$ \\ *corresponding author \\ ian.schipper@vuw.ac.nz \\ $+64(0) 44638197$ \\ ${ }^{1}$ School of Geography, Environment and Earth Sciences, Victoria University of Wellington, PO Box \\ 600 , Wellington 6140, New Zealand \\ ${ }^{2}$ Institute of Geosciences, Johannes Gutenberg University, Mainz, Germany \\ ${ }^{3}$ Earth and Environment, University of Canterbury, Private Bag 4800, Christchurch, New Zealand \\ ${ }^{4}$ Lancaster Environment Centre, Lancaster University, LA1 4YQ, UK \\ ${ }^{5}$ Department of Earth Sciences, Durham University, Durham, DH1 3LE, UK \\ ${ }^{6}$ Department of Earth and Planetary Sciences, McGill University,3450 Rue University, Montreal, \\ Quebec H3A0E8, Canada \\ ${ }^{7}$ Department of Earth Sciences, Uppsala University, Uppsala, Sweden \\ ${ }^{8}$ U.S. Geological Survey, 1711 Illinois St., Golden, CO, 80401, USA \\ ${ }^{9}$ Department of Chemical and Physical Sciences, University of Toronto, Mississauga, Ontario, L5L, \\ Canada \\ ${ }^{10}$ Instituto de Estudios Andinos, UBA-CONICET, Buenos Aires, Argentina \\ ${ }^{11}$ School of Environment, The University of Auckland, Private Bag 92019, Auckland, New Zealand \\ 12 Núcleo Milenio Paleoclima, Centro de Estudios del Clima y la Resiliencia, and Departamento de \\ Ciencias Ecológicas, Universidad de Chile, Santiago, Chile
}

\section{Abstract}

Understanding the processes that drive explosive-effusive transitions during large silicic eruptions is crucial to hazard mitigation. Conduit models usually treat magma ascent and degassing as a gradual, unidirectional progression from bubble nucleation through to magmatic fragmentation. However, there is growing evidence for the importance of bi-directional clastogenic processes that sinter fragmented materials into coherent clastogenic magmas. Bombs that were ejected immediately before the first emergence of lava in the 2011-2012 eruption at Cordón Caulle volcano (Chile) are texturally heterogeneous composite assemblages of welded pyroclastic material. Although diverse in density and appearance, SEM and X-Ray tomographic analysis show them all to have been formed by multigenerational viscous sintering of fine ash. Sintering created discrete clasts ranging from obsidian to pumice and formed a pervasive clast-supporting matrix that assembled these clasts into a conduitsealing plug. An evaluation of sintering timescales reveals texturally disparate bomb components to represent only minutes of difference in residence time within the conduit. Permeability modeling indicates that the plug was an effective conduit seal, with outgassing potential - even from towhighporosity regions - being limited by the inability of gas to flow across tendrils of densely sintered interclast matrix. Contrary to traditional perspectives, declining expressions of explosivity at the surface need not be preceded or accompanied by a decline in fragmentation efficiency. Instead, they result from tips in balance between the opposing processes of fragmentation and sintering that occur in 
countless cycles within volcanic conduits. These processes may be particularly enhanced at silicic fissure volcanoes, which have laterally extensive subsurface plumbing systems that require complex magma ascent pathways. The textures investigated here reveal the processes occurring within silicic fissures to be phenomenologically identical to those that have been inferred to occur in tuffisite veins conduits are essentially being-supersized examples of edifice-penetrating tuffisite veins.

Keywords: Cordón Caulle, rhyolite, sintering, explosive-effusive transition

\section{Introduction}

Silicic eruptions are among the most destructive of naturally occurring phenomena. Many undergo an explosive-to-effusive transition, when widespread pyroclast dispersal is followed by relatively gentle outpourings of lava (e.g., Eichelberger and Westrich 1981; Eichelberger et al. 1986; Adams et al. 2006; Castro and Gardner 2008). Transitions are generally thought to involve intrinsic shifts from closedsystem degassing that promotes rapid magma ascent and fragmentation, to open-system degassing that promotes gas escape, slow magma ascent, and preservation of melt coherence (e.g., Taylor et al. 1983; Eichelberger et al. 1986; Newman et al. 1988; Degruyter et al. 2012). They can also be linked to extrinsic controls such as declining magma ascent rates driven by changes in conduit geometry or exhaustion of magma supply (Nguyen et al. 2014; Cassidy et al. 2018). Understanding these transitions is critical, as each marks a dramatic decline reduction in the footprint of an eruption's impact footprint, and is a key milestone in hazard mitigation (Elissondo et al. 2016).

Fragmentation was long considered to be the defining feature of explosive eruptions (Eichelberger 1995) but there is now abundant evidence that fragmentation and explosivity are not synonymous. Localized fragmentation and shear fracturing in conduits can aid outgassing without causing explosivitytriggering explosive pyroclastic discharge to the surface (Gonnermann and Manga 2003; Rust et al. 2004). Transient fractures, or tuffisites, within and around magma-filled conduits can facilitate outgassing and overpressure modulation during predominantly effusive activity (Stasiuk et al. 1996; Tuffen et al. 2003; Tuffen et al. 2008; Cabrera et al. 2011; Castro et al. 2012; Kolzenburg et al. 2012; Cabrera et al. 2015; Kendrick et al. 2016; Saubin et al. 2016; Farquharson et al. 2017; Kolzenburg et al. 2019). Furthermore, even extensive fragmentation can be reversed by viscous sintering or welding of previously fragmented material (Quane and Russell 2005; Vasseur et al. 2013; Wadsworth et al. 2014; Gardner et al. 2017; Gardner et al. 2018, 2019; Heap et al. 2019). Still, existing conduit models seeking to describe explosive-effusive transitions require that some threshold for shifting activity be defined, and typically do so by investigating if ascending magma does or does not meet one of several criteria for fragmentation (Gonnermann and Manga 2003; Spieler et al. 2004; Degruyter et al. 2012; Nguyen et al. 2014; Cassidy et al. 2018).

A hindrance to understanding explosive-effusive transitions partly stems from the difficulty of identifying eruptive products that exemplify the physical state(s) of magma within conduits-intransition (Adams et al. 2006). Explosive-effusive transitions appear as instantaneous events in the rock 
84

record (Taylor et al. 1983; Newman et al. 1988). Samples of early pyroclasts and later lavas provide insight about how end-member degassing regimes ultimately differed (Castro and Gardner 2008; Nguyen et al. 2014), but do not necessarily capture the crucial time window when eruption styles were dramatically shifting (Adams et al. 2006; Isgett et al. 2017). Furthermore, the effusive phase of silicic eruptions often produces vent-capping lava domes (c.f. Chaitén; Pallister et al. 2013)(c.f. Chaitén; Pallister et al., 2013), which can exacerbate erasureconceal of critical transitional eruption products. The 2011-2012 rhyolite eruption of Cordón Caulle volcano (Chile) provides an unprecedented opportunity to investigate the textural state of magma that was in the conduit during a closely observed explosive-effusive transition, in with hich lava that flowed efficiently away from its source vent (Tuffen et al., 2013).

1.1 The Cordón Caulle fissure, and eruptive transitions in 2011-2012

Cordón Caulle is a $15 \mathrm{~km}$ long and $4 \mathrm{~km}$ wide NW-SE trending fissure system within the <100 ka Puyehue-Cordón Caulle Volcanic Complex (PCCVC) in the Southern Chilean Andes. Cordón Caulle has been the site of the last three PCCVC eruptions, with rhyolite erupted from a variety of vents in 192122, 1960, and 2011-12 (Gerlach et al. 1988; Lara et al. 2006; Castro et al. 2013). The 1960 eruption was significant for having begun 38 hours after the $\mathrm{Mw}=9.5$ Valdivia earthquake, and for creating a series of $>20$ vents. It has thus inspired analysis of the links between regional tectonics and eruption triggers, and demonstrated significant structural controls on silicic magma pathways in fissure systems (Lara et al. 2004; Delle Donna et al. 2010; Sawi and Manga 2018). The 2011-12 eruption began on June 4, 2011, with a Plinian eruption column that dispersed rhyolite tephra across Argentina and disrupted airspace throughout the southern hemisphere (Elissondo et al. 2016). It remains the largest terrestrial eruption to-date of the $21^{\text {st }}$ century and is only the second eruption of rhyolite (after Chaiteén, 2008) to have been directly observed by scientists.

The explosive-effusive transition at Cordón Caulle was protracted, occurring over many months. Plinian explosivity began on June 4-5, 2011, with an eruption column that reached $>14 \mathrm{~km}$ (SERNAGEOMIN/OVDAS 2011). Effusive activity began when lava emerged from the vent on June 15, and continued until late 2012 (with endogenous lava advance continuing into 2013; Tuffen et al. 2013). But the style of explosivity changed character several times in the lead-up to lava emergence, and explosivity did not cease upon commencement of effusion (Castro et al. 2013; Castro et al. 2014).

Several key changes in eruption dynamics preceded the first emergence of lava at Cordón Caulle (Fig. 1C-D). June 7 saw a shift from tephra-depositing pyroclastic columns and density currents, to a period that included both sustained tephra emission and the ballistic ejection of bombs (Pistolesi et al. 2015). This onset of ballistic activity coincided with the beginning of intense uplift in the vent region, indicating that magma was starting to be emplaced as a laccolith in the shallow subsurface (Castro et al. 2016). Edifice inflation, tephra dispersal, and bomb ejection continued for 4-5 days, culminating in an intense period of ballistic activity on Jun 12-13, which was the last major event before lava emergence (SERNAGEOMIN/OVDAS 2011; Silva Parejas et al. 2012; Pistolesi et al. 2015; Castro et al. 2016). 
121 Following lava emergence, the eruption entered into "hybrid" activity (Lara 2008; Castro et al. 2012;

122 Silva Parejas et al. 2012; Castro et al. 2013) that included explosions and effusion from a common vent

123 system. Hybrid activity lasted through early 2012, and progressively waned in intensity (Castro et al.

124 2013; Schipper et al. 2013). Despite these complex overlaps in style, the eruption can be understood to

125 have undergone a protracted transition from predominantly explosive to predominantly effusive, with

126 a commensurate decline in the eruption's tephra hazard footprint.

127 The fissural character of the Cordón Caulle system was less dramatically expressed at the surface in

128 2011-2012 than it had been in the previous two eruptions (e.g., Lara et al. 2004). All of the 2011-2012

129 explosive and effusive activity occurred from a relatively focused vent (apparent vent shifts in Fig.1A-F

130 being a function of off-nadir MODIS viewing angles; Wang et al. 2011). However, the laterally extensive

131 nature of the Cordón Caulle plumbing system was apparent in pre- and syn-eruptive deformation

132 patterns captured in INSAR interferograms by Jay et al. (2014). They documented several deformation

133 centres distributed along the structurally controlled NW-SE trend of Cordón Caulle, most notably two

134 deflation centres 2-10 km from the 2011-2012 vent, that were active from May 8 - June 7, 2011.

135 Furthermore, although the 2011-2012 vent shifts were not as dramatic in 1960, satellite images (Fig.

$1361 \mathrm{G}$ ) and observations (Schipper et al. 2013) of hybrid activity showed concurrent activity of multiple

137 sub-vents, also aligned in a NW-SE trend, at many points during the eruption.

138 We present textures of bombs from Cordón Caulle, predominantly focusing on those that were ejected

139 during the high-energy ballistic episode that bridged initial (exclusively) explosive activity with

140 subsequent (hybrid) effusive activity (SERNAGEOMIN/OVDAS 2011; Castro et al. 2013; Pistolesi et al.

141 2015). These texturally complex bombs have been noted and partially described by several authors

142 (Castro et al. 2014; Pistolesi et al. 2015; Paisley et al. 2019a; Paisley et al. 2019b). We use bomb textures

143 to gain insight into the state of magma within silicic fissures and their associated subvolcanic conduits

144 in the lead-up to an explosive-effusive transition. We examine the processes that drive conduit closure

145 and discuss the seeming dichotomy that opposing clastogenic processes (fragmentation versus

146 sintering) can both prolong and extinguish explosivity from a constricting silicic system.

\section{Samples and methods}

148 Bombs were mapped and examined in vent-proximal and -distal field locations over five field seasons 149 from 2013-2017. In November 2017, we carried out an aerial survey of the 2011-2012 Cordón Caulle 150 vent and lava flow, using an $\mathrm{XCam}^{\circledast}$ camera fixed to a Cessna ${ }^{\circledR} 152$ airplane, which collected a suite of 151 high-resolution (7cm/pixel) orthophotos (Fig. 2B-C). Hundreds of bombs were examined in the field, 15226 in collected hand samples, 21 in thin section, and 13 with X-Ray computed tomography (CT). Table 1531 provides a representative suite of documented bombs and the analyses performed on each. 
Victoria University of Wellington. Particle sizes on selected BSE images were measured using Image (Schneider et al. 2012) Imaget.

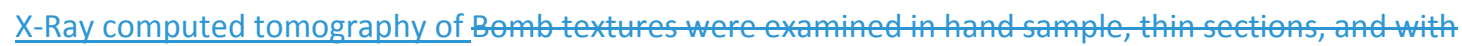
X-Ray computed tomography (CT) at two different scales ( 13 and $\sim 1.5 \mu \mathrm{m})$. Llarge samples $(\leq 10 \mathrm{~cm})$ were-was performedscanned in Hutch 3B of the Imaging and Medical Beamline at the Australian Synchrotron (Clayton), using their Ruby detector, $30 \mathrm{keV}$, and $0.8 \mathrm{~s}$ exposure time over $180^{\circ}$ rotations, yielding reconstructed scans with voxel edge-lengths of $\sim 13 \mu \mathrm{m}$. One bomb from this suite (P14-B02; Table 1, Fig. 3E) was then selected for high-resolution CT with the RX-Solutions Rescan at l'Université de Grenoble Alpes (France), after it was determined to be representative of Cordón Caulle composite bombs, and to contain the full spectrum of observed components within them (see Section 3)was selected for high-resolution CT with the RX-Solutions Rescan at I'Université de Grenoble Alpes (France). This onee bomb was sawn in half with a rock saw, and a small coring tool was used to extract $3 \mathrm{~mm}$ diameter cores from selected regions of interest. Each core was scanned using a LaB6 filament, $45 \mathrm{keV}$, $180^{\circ}$ rotation, and $10 \mathrm{~s}$ exposure time, yielding reconstructed central subvolumes with voxel edge lengths of $1.5 \mu \mathrm{m}$. Image stacks were manipulated using ImageJ(Schneider et al. 2012) and volumes rendered using Drishti Image (Limaye 2012). The Darcian permeabilities of selected CT subvolumes were modeled by Lattice Boltzmann simulation (Degruyter et al. 2010). Subvolumes for permeability simulation were $250 \times 250 \times 500$ pixels, with flow simulated along the long direction. We used a low model inlet pressure (0.0005 MPa), and following Degruyter et al. (2010) we verified that an increase or decrease of this inlet pressure by more than two orders of magnitude did not result in any changes in modeled permeability, ensuring flow was in the low Reynolds (laminar) and Mach number regimes.

Polished thin sections of selected bombs were examined with backscatter electron (BSE) imaging and semi-quantitative Energy Dispersive X-Ray Spectroscopy (EDS) on the JEOL JXA-8260 Superprobe at Victoria University of Wellington.

\section{Results}

\subsection{Bomb distributions and types}

The "proximal" bomb field occupies a radial area $<400 \mathrm{~m}$ from vent (Fig. $2 \mathrm{~A}$ ), and corresponds to the range of ballistic bomb deposition (impact and down-slope rolling/bouncing) observed during waning hybrid activity in January 2012 (Schipper et al. 2013). It is littered with countless blocks and bombs ranging from the decimetric scale to a maximum of 2.5 metres across (Fig. 2B,D). The "distal" bomb field extends to up to $3.1 \mathrm{~km}$ from the vent, skewed toward the west/northwest (Fig. 2A). It is comprised of many bombs up to $\sim 1$ metre in size (although usually just remnant fragments of what were larger

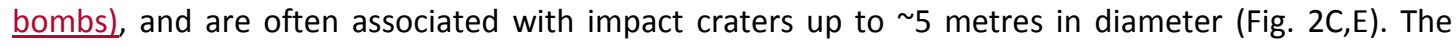
craters are several 10s of centimeters deep, and usually surrounded by a rim of pyroclastic debris that is coarser than the ash plain that they punctuate (Fig. 2E). Some craters cannot be linked to any specific bomb, indicating that the ballistics bounced, rolled, shattered, or were buried in the substrate they impacted (Fitzgerald et al. 2014). 
193 Proximal bombs are the most texturally homogeneous of any observed at Cordón Caulle. Our fieldwork

194 shows that most ( $\sim 0 \%$ ) are angular, dense, and texturally similar to outer portions of the coherent

195 lava flow. Their dull grey colour is similar to that of lava samples with $>60 \%$ microlites in the groundmass

196 (Schipper et al. 2019). They often have vesicles with a "frosted" appearance, similar to the vapour-

197 phase cristobalite-bearing vesicles that are common in the lava flow (Schipper et al. 2015; Schipper et

198 al. 2020) (Fig. 3A). The remaining ( 20\%) of proximal bombs are flow-banded and partially breadcrusted

199 obsidian (Fig. 3B). Distal bombs (> $400 \mathrm{~m}$ to $3.1 \mathrm{~km}$ ) are distinctly different. They are almost exclusively

200 composites, or welded assemblages of many different particles (Fig. 3C-J). We refer to them as

201 "composite bombs", and note that they have been previously described as "spectacularly welded"

202 bombs by Pistolesi et al. (2015), "pumice breccia" bombs by Castro et al. (2014), and "non-oxidized

203 breccias" by Paisley et al. (2019b). Composite bombs are not apparent in our orthophotographs of the

204 surface of the lava flow (Fig. 2B,D), although poor bomb/crater preservation would be expected on the

205 lava itself (e.g., Fitzgerald et al. 2014). Our observations of composite bomb distribution are consistent

206 with the stratigraphic reconstruction of Pistolesi et al. (2015) and observations of

207 SERNAGEOMIN/OVDAS (2011) that link distal (composite) bomb emplacement to the high-energy

208 ballistic phase of June 12-13 (Fig. 1Eㅌㅁ).

209 The lava-like proximal bombs do not show any sign of post-eruptive expansion or textural modification,

210 and may be more accurately described as blocks (Fig. 3A). Partial expansion of proximal obsidian bombs

211 is however apparent in preferential foaming along flow bands (Fig. 3B). Conversely, most composite

212 bombs show evidence of having significantly expanded, or breadcrusted, after ejection. Some of the

213 composite bombs have clear breadcrusting patterns on their surfaces (Fig. 3C), but in others the

214 expansion is apparent in them being friable and having large and oxidized cavities in their interiors (Fig.

215 3D). The composite bombs appear to have breadcrusted en masse, such that at the time of ejection

216 each bomb expanded as a single entity, with central cavities forming regardless of there being

217 boundaries between the components within them.

218 The heterogeneity of the composite bombs is extreme. Over several field campaigns, the authors

219 deliberated on how to best characterize them. Proposed types included "breadcrust bomb" (e.g., Fig.

220 3C), "pumice breccia" (e.g., Fig. 3D-F; Castro et al. 2014), "tuffisites" (Paisley et al. 2019a), "obsidian

221 breccia” (e.g., Fig. 3G-H), "pebble bombs" or "honeycomb” (e.g., Fig. 3I; Whattam 2018), and "obsidian

222 bombs with/without pumice" (e.g., Fig. 3J). Ultimately, these categories proved to have limited

223 usefulness due to the large variability within them and gradational differences between them.

224 Furthermore, field mapping showed no relationship between composite bomb type and distribution

225 patterns. Here, we distil these categories into a unifying textural class of "composite" bombs:

226 heterogeneity being their unifying characteristic.

$227 \quad 3.2$ Components of composite bombs

228 Composite bombs consist of assemblages of clasts with relatively homogenous internal textures and 229 clear boundaries, bound together by borderless domains of matrix (Fig. 3D-H). The volume occupied by 
230 clasts is usually greater than that occupied by the matrix, with matrix often occupying sinuous inter-

231 clast interstices (Fig. 3D-H). Rarely, clasts are relatively sparse and fully matrix-supported (Fig. 3I). In

232 other rare bombs, no matrix is visible in hand sample; the composite nature of these pyroclasts is

233 apparent in there being clasts of one texture fully embedded in larger domains of another (Fig. 3J).

234 Individual composite bombs can look vastly different to each other, but are ultimately unified by being

235 composite, each composed of a heterogeneous assemblage of clasts that are bound together by

236 variable amounts of matrix material.

237 Clasts within composite bombs range from dense obsidian to highly vesicular pumice, with rare 238 crystalline lithics. Even when a bomb is dominated by one type of clast, the presence of other types is 239 common and striking (e.g., rare or minor obsidian within the pumice-dominated bombs of Fig. 3D-F, 2404 A-B). Further textural complexity is apparent within clasts when they are viewed in thin section (Fig.

241 4B) and BSE images (Fig. 4C-H).

242 Obsidian clasts range in size from few millimetres (Fig. 4B) to occupying almost the entirety of 243 decimetric bombs and bomb fragments (Fig. 3J). Some obsidian is homogeneous, hypocrystalline 244 rhyolitic glass (labeled "homogeneous obsidian" in Fig. 4C). Other obsidian has more complex microtextures in which unequivocal evidence for clastic origins are-is preserved ("clastogenic obsidian" of Fig. 4C) (Castro et al. 2014). This evidence includes greyscale variations in BSE images that delineate

247 where original (but now highly deformed) particle boundaries had been before densification (inset to

248 Fig. 4C). It also includes the presence of mafic domains that are compositionally distinct to the dominant 249 rhyolite, and could only have been incorporated as particles (Fig. 4C; see section 3.3). Individual obsidian clasts often contain regions that appear homogenous, and others that are obviously 251 clastogenic (Fig. 4C,D).

252 Pumice clasts are white-to-beige, cover a similarly broad size range to the obsidian, and can be subdivided into two textural types. The first is "borderless" (sensu Saubin et al. 2016), with 254 homogeneous textures throughout and no difference in vesicle texture from clast interiors to rims (Fig. $2554 \mathrm{E}, \mathrm{H})$. Borderless pumices are usually flattened/deformed into angular-tipped fiamme. These tend to 256 be aligned with adjacent pumice clasts to define a fabric similar to that in pumice-rich welded ignimbrites (Quane and Russell 2005; Wright and Cashman 2014) (e.g., inset to Fig. 3D, Fig. 4B). Other pumice clasts have large, extensively coalesced vesicles at their centres, but a radial gradation; first toward smaller, more isolated and increasingly flattened vesicles, and then to dense glassy margins (Fig. 4D-F). These are similar to the "pale vesicular clasts" with degassed borders that were described in tuffisites from Chaitén volcano (Saubin et al. 2016), and similar textures have been produced in experiments on expanding obsidian and shriveling pumice (Kennedy et al. 2016; von Aulock et al. 2017).

263 We describe these as "foamed" pumice, as in most cases they appear to have isotropically expanded in 264 situ within composite bombs (Fig. 4D,E). Although most of the foamed pumices are spheroidal, some 265 are irregular in shape and have truncated vesicles that suggests they are no longer in situ (Fig. 4F). In particular, within matrix-dominated composite bombs (Fig. 3I) the foamed pumices have a flattened 
267 vesicular fabric that is oblique to the clast margins and these may have been rounded by abrasion in

268 fluidized matrix material rather than foaming in situ.

269 The matrix is usually oxidized to brown or red in hand sample (Fig. 3D-I) and thin section (Fig. 4B). The 270 degree of oxidation in Cordón Caulle pyroclastic material has previously been linked to the inverse 271 depth of formation within the conduit (Paisley et al. 2019b), but here we note that oxidation also varies radially within the-breadcrusted composite bombs (inset to Fig. 3D). In clast-dominated bombs, the matrix is in inter-clast tendrils that range in thickness from a few 10s of micrometers $\mu \mathrm{m}$ up to $10 \mathrm{~mm}$ (Fig. 3E-F, 4B). In BSE images, it is clear that the matrix is comprised of ash particles (Fig. 4D-H). The particles have an strong modal diameter of 10-20 $\mathrm{mm}$, with only rare particles up to $160 \mu \mathrm{m}$ (Whattam 2018) and) that are preserved in various states of viscous sintering (Vasseur et al. 2013; Wadsworth et al. 2014) and compaction (Wadsworth et al. 2019) (Fig. 4D-H). Even within the area covered by a single thin section (Fig. 4B), matrix domains of similar sizes are preserved in vastly different states, from relatively porous (Fig. 4E) to almost completely dense (Fig. 4G). Furthermore, many high-porosity regions in the matrix have clearly foamed in situ. Similar to the foamed pumice clasts, these domains have dense margins but central cavities of large and extensively coalesced vesicles (Fig. 4H). Figure 5 shows the size distribution of 1525 ash particles, as measured on 61 BSE images from nine different composite bombs. The measured particles were mainly in matrix domains, but also included particles that were visible within clastogenic obsidian. Sintering particles have a strong modal diameter of $10-$ $20 \mu \mathrm{m}$ (45\% of the counted particles), with rare particles up to $\sim 175 \mu \mathrm{m}$.

\subsection{Mafic component in composite bombs}

287 There is compositional complexity in the Cordón Caulle composite bombs. Clastogenic domains (both 288 clasts and matrix) contain a minor but pervasive mafic component (Fig. 4C-G). The mafic glass is basaltic andesite $\left(55.6\right.$ - 62.1 wt\% $\left.\mathrm{SiO}_{2}\right)($ Whattam 2018$)$ that is brighter in BSE images than the low-silica rhyolitic glasse $\left(70.1-72.7 \mathrm{wt} \% \mathrm{SiO}_{2}\right)$ that makes up the majority of the composite bombs, the pretransition Plinian ejecta, and post-transition lava flow (Castro et al. 2013; Schipper et al. 2019). Mafic

292 particles are usually in the ash size range $(<2 \mathrm{~mm}$ ) but occasionally as big as small lapilli (Fig. 4B).

293 Regardless of the local degree of sintering, boundaries between mafic and rhyolitic particles are sharp, 294 and do not form compositionally mixed continuums-continua along inter-particle necks (Fig. 4F,G). 295 Mafic particles range from being glassy to having holocrystalline groundmass rich in quench microlites. 296 Here, we simply use the presence of the mafic particles as a useful indicator of the clastogenic origin of 297 any clast or domain in which they are hosted. Their presence reveals compositional complexity in the 298 magmatic system that fed the 2011-2012 Cordón Caulle eruption, and their compositions, origins, and significance are currently being examined in a companion study.

$300 \quad 3.4$ X-Ray Computed Tomography and permeability modeling

301 Low-resolution (13 $\mu \mathrm{m} /$ voxel edge) CT scans provide an overview of the structure of composite bombs. 302 In a low-density clast-dominated bomb, the irregular shapes and high-curvature or pointed tips of \$03 borderless pumice clasts are apparent (Fig. $5 \underline{\mathrm{Fig} .6 \mathrm{~A}}$ ). The matrix in this case is in relatively thin inter- 
B04 clast domains that appear to suture neighbouring clasts together (Fig. 5Fig. 6A) (Gardner et al. 2017). In a rare but striking matrix-dominated bomb (Fig. 2l, and also Fig. 2b of Heap et al. 2019) banding of variable density is apparent in the matrix that wraps around the isolated pumice clasts (Fig. 5Fig. 6B). These are similar to the fine and coarse laminations observed in tuffisite veins within composite bombs described by Paisley et al. (2019a).

To investigate how sintering influenced open- and closed-system degassing, permeability modeling was performed on sub-volumes digitally extracted from high-resolution CT scans (Fig. 5Fig. 6C-D). The 1.5 $\mu \mathrm{m} / \mathrm{voxel}$ edge resolution of these scans ensured that key permeability-controlling structures such as thin glass walls in vesicular regions and small interstitial pores in sintering regions were accounted for in the flow simulations. Four types of sub-volumes were digitally isolated. The first three captured singular textural domains: obsidian, pumice, or matrix. The fourth was a set of composite sub-volumes (e.g., Fig. 5Fig. 6D) in which gas flow through variably textured domains was simulated (Fig. 5Fig. 6D-E). These were selected to investigate the effect of textural heterogeneity on porosity and permeability. Obsidian clasts have porosity $(\phi)$ ranging from 0.07 to 0.17 , and permeability (k) that spans three orders of magnitude, from $1 \times 10^{-19}$ to $6.5 \times 10^{-16} \mathrm{~m}^{2}$. However, most of these have permeability $<10^{-18} \mathrm{~m}^{2}$, with only one sample that had both the lowest porosity and highest permeability in the obsidian suite. Pumice clasts have porosity ranging from 0.66 to 0.75 , and permeability ranging from $9.3 \times 10^{-13}$ to

$3216.8 \times 10^{-12} \mathrm{~m}^{2}$. The matrix has intermediate porosity ranging from 0.20 to 0.58 , and permeability from $1.4 \times 10^{-14}$ to $2.1 \times 10^{-12} \mathrm{~m}^{2}$ (Fig. 5 Fig. 6 E).

A Kozeny-Carman type power-law best fit $\left(R^{2}=0.68\right)$ to the matrix subvolumes is:

The fit to the matrix is strikingly similar to the scaled porosity-permeability relationship defined for sintering of volcanic ash with an initial particle diameter of $10 \mu \mathrm{m}$ (Wadsworth et al. 2016), which is significant when recalling that the matrix formed by sintering of ash with a diameter of $\sim 10-20 \mu \mathrm{m}$ (Fig. 5). The best fit to the matrix extends to describe the porosity-permeability data from pumice clasts in the composite bombs, however all but one of obsidian clasts have dramatically lower permeability.

330 An example pumice-dominated sub-volume (Fig, $4 \mathrm{D}$, example i) has porosity of 0.70 and permeability 331 of $4.2 \times 10^{-12} \mathrm{~m}^{2}$, consistent with the data from pumice clasts. However, sub-volumes with more dramatic composite textures have permeabilities that are highly variable. In most cases they have lower permeability than matrix with equivalent porosity. This is most pronounced in the high-porosity composites $(\phi>0.5)$ where modeled permeabilities are up to two orders of magnitude lower than expected from the best fit to the modeled matrix (Fig. 5Fig. 6E). Many of the composite subvolumes fall within or below the porosity-permeability curves defined for fabric-parallel and -perpendicular multicomponent welded ignimbrites (Wright and Cashman 2014). Furthermore, the Wright and Cashman (2014) field encompasses only slightly higher permeability than that measured in a core extracted from a matrix-dominated Cordón Caulle composite bomb (Heap et al. 2019). The material 
measured by Heap et al. (2019) was extracted from the same matrix-dominated composite bomb shown in Figures $2 \mathrm{I}$ and 5B. We did not scan this bomb at high resolution and therefore cannot directly compare our modeled permeability with their measurements but note that such matrix-dominated bombs are relatively rare at Cordón Caulle.

344 Overall, the modeled porosity-permeability relationship for the matrix is consistent with the expected

345 trend for viscous sintering of fine ash (Wadsworth et al. 2016). However, heterogeneous subvolumes

346 of the Cordón Caulle composite bombs, which include multiple types of domains and interfaces 347 between them are highly variable. They are more consistent with the porosity-permeability 348 relationships observed in welded, multicomponent volcanic materials, especially at higher porosities 349 (Wright and Cashman 2014; Heap et al. 2019).

\section{Discussion}

3514.1 Composite bombs: clastogenic remnants of a conduit in transition

352 The high-energy ballistic emplacement of composite bombs bridged subplinian explosivity and lava flow 353 emergence at Cordón Caulle (SERNAGEOMIN/OVDAS 2011; Castro et al. 2013; Pistolesi et al. 2015). The 354 bombs themselves therefore represent the best available evidence of the textural state of magma in the shallow conduit when it was undergoing the explosive-effusive transition. Within the classical view that such transitions are controlled by a shift from closed- to open-system degassing (Eichelberger et al. 1986; Giachetti et al. 2020), magma in transitioning conduits might be expected to be highpermeability foams, or to be intensely crosscut by high-permeability fractures. Instead, the conduit was filled with a heterogeneous mixture of previously fragmented and variably welded/sintered clastic material, with permeability often much lower than expected for an equivalent magmatic porosity (Fig. 5Fig. 6E). This indicates that magmatic processes of textural evolution (e.g., vesiculating melt) played less of a deterministic role than clastogenic processes (e.g., fragmentation and sintering) in controlling outgassing, shifts in eruption style, and final textural evolution of eruptive products.

Magmatic processes describe a melt ( \pm crystals) evolving by bubble nucleation, growth, and coalescence (Sparks 1978; Cashman and Mangan 1994). The fate of gas within the pore space is controlled by a hysteresis loop relative to percolation and permeability thresholds (Rust and Cashman 2004) that determine if the magma ultimately meets one of several criteria for fragmentation or outgases to be preserved as a coherent body of lava (e.g., Alidibirov and Dingwell 2000) (Fig. 6Fig. 7). It is increasingly recognized that clastogenic processes can also cause fragmented material to enter a qualitatively similar evolutionary path, albeit with significantly different threshold values (Tuffen et al.

371 2003; Tuffen and Dingwell 2005; Castro et al. 2012; Vasseur et al. 2013; Wadsworth et al. 2014;

B72 Wadsworth et al. 2016; Gardner et al. 2017; Gardner et al. 2018, 2019) (Fig. 6Fig. 7). Viscous sintering 373 reduces porosity and permeability (Wadsworth et al. 2014; Kendrick et al. 2016; Wadsworth et al. 2016; \$74 Gardner et al. 2017), and increases strength (Kolzenburg et al. 2012; Vasseur et al. 2013). Sintering can 375 ultimately yield a continuous melt (Gardner et al. 2018, 2019), and recent work even indicates that 376 silicic lavas themselves may be generated in this way (Wadsworth et al. 2020). The most important 
377 difference between the magmatic and clastogenic evolutionary cycles is their percolation thresholds,

378 which are an order of magnitude greater in vesiculating melts $(\phi \sim 0.3)$ than in sintering masses $(\phi \sim 0.03)$

379 (Wadsworth et al. 2016).

380 Magma rise in the Cordón Caulle conduit must have started with magmatic textural evolution as the 381 rhyolite melt ascended from its 5-10-9 km pre-eruptive storage zone (Castro et al. 2013; Delgado 2020), 382 but clastogenic processes dominated textural evolution in the lead up to the explosive-effusive 383 transition. The matrix in composite bombs is clearly a product of viscous sintering (Fig. 4E-G). Further, B84 the clasts (lithics excepted) can be linked to different stages of clastogenic textural evolution (Fig. $6 \mathrm{Fig}$. 385 7). Some obsidian is demonstrably clastogenic (inset to Fig. 4C), but "homogenous" obsidian (Fig. 4C) 386 could equally be clastogenic but with evidence of the original particles having been completely erased.

B87 The absence of preserved particle outlines in "homogeneous" obsidian at Cordón Caulle is not 388 necessarily evidence against it having had clastogenic origins. Here, it is noteworthy that residual water 389 contents in pyroclastic obsidian at Cordón Caulle are very low (<0.3 wt.\%; Schipper et al. 2013; Castro 390 et al. 2014)_compared to those found at other silicic volcanoes such as Mono Craters ( $\leq 2.71 \mathrm{wt} . \%$; 391 Newman et al. 1988) or Chaitén ( $\leq 1.6$ wt.\%Castro et al. 2014; Forte and Castro 2019). Although this is 392 not in itself conclusive evidence that all Cordón Caulle obsidian is clastogenic, low residual $\mathrm{H}_{2} \mathrm{O}$ would 393 be expected if the obsidian clasts formed by sintering of shallowly-degassed fine ash. Furthermore, 394 while the "borderless" pumice may represent portions of a magmatic foam, the "foamed" pumice (and 395 matrix) appear to have expanded in situ. These pumices may also be clastogenic, with foaming having 396 been driven by exsolution of residual $\mathrm{H}_{2} \mathrm{O}$ from sintered melt, or by thermal expansion of $\mathrm{H}_{2} \mathrm{O}$ that was 397 entrapped between particles during the sintering process (Saubin et al. 2016; von Aulock et al. 2017; 398 Forte and Castro 2019; Browning et al. 2020). Textures within the Cordón Caulle composite bombs 399 demonstrate the importance of clastogenic textural evolution in a silicic conduit (Fig. 6Fig. 7), and 400 highlight the vastly different textural states of melt that can be generated and closely juxtaposed within 401 a transitioning conduit (Saubin et al. 2016; Isgett et al. 2017; Paisley et al. 2019b; Wadsworth et al. 402 2020).

403 Vulcanian eruptions often produce breccia bombs that demonstrate there to have been an abundance 404 of fragmental material in the subsurface. The Cordón Caulle composite bombs are different from typical 405 vent breccias (e.g., Yamagashi and Freebrey 1994) in that they have very low abundances of 406 lithic/accidental clasts, and are instead comprised of juvenile products preserved in various states of 407 viscous sintering(Yamagashi and Freebrey 1994). Although some proportion of the composite bombs' 408 components may have accumulated by fallback into the vent, the assembly of these components into 409 a composite mass was clearly driven by continuous delivery of fresh ash from below. The most striking 410 evidence for this is the mafic component within the bombs' clasts and matrix. No surface expression of 411 mafic melts was documented during the 2011-2012 Cordón Caulle eruption, and no deposits of this 412 compositionally distinct material have been found in our fieldwork. We conclude that the composite 
413

bombs represent material delivered directly from the subsurface to the shallow vent region, where it accumulated and sintered to various degrees.
4.2 No decline in fragmentation in the lead-up to effusion

The classical traditionalequivalency drawn between fragmentation and explosivity is continually under scrutiny has been challenged in recent times (e.g., Wadsworth et al. 2020). In its traditional form, this argument implies-This traditional model posited that a decline in fragmentation efficiency - which is inversely proportional to the grainsize of the resulting particles (Kueppers et al. 2006) - should be expected in the lead-up to an explosive-effusive transition. If viewed macroscopically, the shift from ejection of sub-Plinian tephra to coarse composite bombs that occurred 8-9 days into the Cordón Caulle eruption (SERNAGEOMIN/OVDAS 2011; Castro et al. 2013; Pistolesi et al. 2015) marked a dramatic reduction in fragmentation efficiency. However, the particles that sintered to form the components of the composite bombs were originally of a very fine grainsize $(\sim 10-20 \mu \mathrm{m} ;$ Fig. 5$)$ - finer than the modal grainsize of any deposits from the preceding explosive activity (Pistolesi et al. 2015; although direct comparison is difficult due to different tranport histories). The sizes of pyroclast upon ejection from a conduit are sometimes inversely linked to fragmentation depths (Dufek et al. 2012). Such a relationship can be logically envisioned for Cordón Caulle, with fine ash, clasts, and composite bombs representing the products of progressively shallower fragmentation events. UThe ultimately, the final fragmentation event that created the bombs may have been of low-efficiency, but the cycles of fragmentation that provided starting materials for sintering of their components were no less efficient than those that produced Plinian tephra. Furthermore, Cordón Caulle sustained an ash column throughout the ejection of composite bombs (Fig. 1E) and subsequent hybrid activity (Fig. 1F-G), indicating that some of the rising magma was being finely fragmented at all times during the eruption.

\subsection{Timescales of in-conduit sintering}

The small initial grainsize $(\sim 10-20 \mu \mathrm{m})$ of the in-conduit granular suspension would have been crucial to composite bomb formation and conduit closure. Sintering-driven matrix densification tracks with time $(t)$ according to the characteristic sintering timescale in the absence of confining stresses $\left(\lambda_{S}\right)$ (Vasseur et al. 2013; Wadsworth et al. 2014):

$\phi(t)=\phi_{i} \exp \left(-\frac{3 t}{2 \lambda_{S}}\right) \quad$ with $\quad \lambda_{S}=\frac{\eta \bar{R}}{\sigma}$

where $\phi_{\mathrm{i}}$ is the initial porosity ( 0.45 for close -packed natural ash particles; Kendrick et al. 2016), and $\lambda$ s depends on particle radius $(R)$, melt viscosity $(\eta)$ and interfacial surface tension $\left(\sigma=0.22 \mathrm{Nm}^{-1}\right)$. Viscosity is estimated to be $2.0 \times 10^{7}$ to $1.6 \times 10^{8} \mathrm{~Pa} \mathrm{~s}$, using the model of Giordano et al. (2008) with an average pyroclast glass composition from Schipper et al. (2019), the 0.04 to 0.31 wt\% range of $\mathrm{H}_{2} \mathrm{O}$ measured in various composite bomb components by Castro et al. (2014), and a temperature of 900 ${ }^{\circ} \mathrm{C}$. This is the upper end of the pre-eruptive storage temperature of the Cordón Caulle magma (Castro et al. 2013), but is justified by morphological inferences that the lava first emerged at $\sim 900{ }^{\circ} \mathrm{C}$ (Magnall et al. 2017). This demonstrates that a high degree of thermal insulation in the conduit was maintained 
through the explosive-effusive transition, and suggests that the approach of lava-forming melt would have provided a significant source of heat to sintering materials entrapped in the upper conduit. The fine initial grainsize of the granular suspension at Cordón Caulle would also have ensured rapid diffusive hydration of sintering particles with hydration timescales $\left(\lambda_{D}\right)$ similar to sintering timescales $\left(\lambda_{S}\right)$ (calculated according to Gardner et al. 2018, 2019). Significant hydration of sintering materials is apparent in the foaming of bomb components (Fig. 4D,E,H) and the overall breadcrusting of composite bombs (Fig. 3C,D).

The time evolution of porosity (Eq. 2) and permeability (Eq. 1) indicate that only 13 (for $\mathrm{H}_{2} \mathrm{O}=0.31$ wt\%) to 109 (for $\mathrm{H}_{2} \mathrm{O}=0.04$ wt\%) minutes would be required for Cordón Caulle's subterranean granular suspension to drop below the percolation threshold $(\varphi=0.03$; Wadsworth et al. 2016). Such rapid sintering timescales can explain why composite bombs can have juxtaposed materials of vastly different porosities and textures: the timescales of textural evolution are short enough that small local variations $\underline{\text { in } \mathrm{H}_{2} \mathrm{O} \text {, grainsize, or temperature could result in closely juxtaposed domains of clastogenic melt }}$ achieving very different positions in porosity-permeability space, even with evolutionary times that were only marginally different (Fig. 7). Nearly identicalSimilarly short times (12 to 98 minutes) would be required for the permeability of the sintering matrix to drop below $10^{-16} \mathrm{~m}^{2}$, a presumed cutoff between open- and closed-system degassing regimes (Collinson and Neuberg 2012). Although care $\underline{\text { must be taken in extrapolating from matrix permeabilities modeled at the micron-scale to inferences }}$ about full conduit closure, we note that matrix-bearing composite domains tend to have permeabilities that are significantly lower than expected for texturally homogeneous materials of equivalent porosity (Fig. 6E). This is presumably because (1) even thin tendrils of intercalated sintered matrix interfere with gas flow through the high-porosity pumiceclasts-domains, and (2) foamed pumice and matrix domains have poorly-vesicular margins that block gas flow (c.f., the closed foams of von Aulock et al. 2017). Therefore, the evolution of permeability within sintering matrix appears to have controlled the permeability evolution over longer lengthscales within the evolving Cordón Caulle conduit, but with anthe important caveat that: our analyses do not capture the influence of large, interconnected pore spaces or pathways that may have existed in Cordón Caulle's shallow conduit. However, (1) the largest of observed pore spaces in Cordón Caulle composite bombs appear to be post-eruptive features; and (2) syn-eruptive observations indicated that preferential degassing pathways through the shallow conduit, although important, were relatively fixed in specific and discrete locations of shear localization within the conduit-plugging lava (Schipper et al. 2013).

Based on the observation that all components of the composite bombs were, or could have once been, finely fragmented material, we propose that the lead-up to the explosive-effusive transition at Cordón Caulle did not involve a reduction in fragmentation efficiency. Instead, maintained (or even increased) fragmentation efficiency yielded a subterranean granular suspension of very fine grainsize that rapidly sintered under hydrous conduit conditions, with commensurate reduction in porosity and permeability, 
and local resorption of $\mathrm{H}_{2} \mathrm{O}$ to yield an impermeable and hydrous plug that was effective in choking off the main explosive phase of the eruption. Interestingly, although the production of fine ash required initial fragmentation to be efficient, the reduction in porosity that accompanies sintering of this material actually raises the amount of energy required to achieve fragmentation thresholds (Spieler et al. 2004). The diminution of tephra plumes at Cordón Caulle occurred because explosivity was "selfextinguishing", as efficient fragmentation actually enhanced the efficacy of sintering. It does not, however, represent a significant decline in fragmentation efficiency or energy.

\subsection{Complex magma ascent in silicic fissures}

494 Any vision of Cordón Caulle's plumbing system needs to accommodate several observed phenomena, including: (1) feeding of the initial Plinian eruption and subsequent changes in explosive character (Castro et al. 2013; Pistolesi et al. 2015); (2) accumulation of unerupted magma (of unconstrained coherence) in a sub-vent laccolith (Castro et al. 2016); (3) multiple, widely spaced deformation centres along the edifice (Jay et al. 2014; Delgado et al. 2016); (4) the recognition that the eruption tapped several similar-but-distinct melt bodies (Alloway et al. 2015); and (5) hybrid explosive-effusive activity (i.e., co-eruption of fragmented and coherent magma; Castro et al. 2013; Schipper et al. 2013). Furthermore, the composite bomb textures require a subsurface architecture that allowed: (1) efficient fragmentation of magma(s) into viscous rhyolite (+/- mafic) particles; (2) accumulation, viscous sintering and textural evolution into domains with textures represented by the clasts of composite bombs; (3) fracturing of these sintered materials to create pathways through and into which additional fine ash could transit and accumulate; and (4) accommodating transit of coherent_, unfragmented-(or clastogenic; Wadsworth et al. 2020) lava-forming magma to the surface.

507 Such wide diversity of processes can be reconciled when remembering that Cordón Caulle is fed by a 508 magmatic fissure system, in which there is significant magma movement laterally as well as vertically 509 (Lara et al. 2006; Castro et al. 2013; Jay et al. 2014). The fissural character of Cordón Caulle was starkly expressed at the surface in the 1960 eruption, in which $>20$ vents opened along a $5.5 \mathrm{~km}$ long NW-SE

511 fissure (Fig. 2A; Lara et al. 2004). Vents were comparatively focused in 2011-2012, but did show some 512 rift-parallel shifts (Fig. 1G), and multiple loci of explosivity were maintained into the waning stages of 513 hybrid activity (Schipper et al. 2013). Furthermore, in the first three days of the eruption, magma was 514 fed from two distinct sources, $2-10 \mathrm{~km}$ along the fissure from the vent (Jay et al. 2014). Magma that 515 rises in a structurally controlled fissure system can exploit pre-existing fractures/faults in accordance 516 with local stress regimes (Lara et al. 2004) such that: (1) magma is not constrained to cylindrical conduit;

517 (2) magma can exploit new paths of least resistance along strike of the fissure in the event of local

518 blockage by sintering or other processes; and (3) magma that erupts explosively and effusively can have 519 had entirely different ascent paths, instead of having to share a common path in which degassing $\$ 20$ regimes are required to change over time (Fig. 87 ).

521 Ultimately, there was no apparent wholesale shift from processes causing explosivity to those causing 522 effusivity at Cordón Caulle. Fragmentation continued throughout the eruption, but efficient sub-surface 
523 sintering eventually diminished its expression at the surface, in a process of "self-extinguishing". A

524 clastic origin for silicic lava itself has been investigated in at Cordón Caulle (Castro et al. 2014), and has

525 recently been argued for silicic lavas in general (Wadsworth et al. 2020). However, no textural evidence

526 has been presented to show that the 2011-2012 lava flow itself has clastogenic origins (e.g., Schipper

527 et al. (2019) found no evidence for mafic particles in their geochemical and textural investigation of $\sim 20$

528 samples from the 2011-2012 lava flow). This bears further investigation and the development of

529 additional methods for examining cryptic and overprinted clastic signatures. However, based on

$\$ 30$ available data, the 2011-2012 Cordón Caulle tava-lava does not appear to have resulted from a

531 progressive decline in fragmentation efficiency, but the arrival of melt that evaded fragmentation - at

$\$ 32$ least during its ultimate exit from the vent. In the case of Cordón Caullethis case, the shift from

533 explosive-to-effusive thus represents two distinctly separate, but overlapping, events: (1) the "self-

534 extinguishing" of explosivity by viscous sintering, and (2) the arrival of coherent melt at the vent. The

535 fact that these types of activity could occur simultaneously may at least partly be because Cordón

536 Caulle's extensive fissure system provides a variety of magma ascent pathways in which decompression

537 rates, shear, and other controls on eruptive style could vary (Taylor et al. 1983; e.g., Eichelberger et al.

538 1986; Newman et al. 1988; Degruyter et al. 2012; Nguyen et al. 2014; Cassidy et al. 2018). It is also

539 important to note that continued fragmentation and sintering-driven conduit closure may have been

540 the mechanism for the explosive-effusive transition at Cordón Caulle, but this does not preclude the

$\$ 41$ transition having been driven or enhanced by extrinsic changes such as declining magma supply or

542 ascent rates (Nguyen et al. 2014; Cassidy et al. 2018).

5434.5 Equivalency of silicic conduits and tuffisite veins

$544 \quad$ Models of the plumbing system and shallow vent architecture at Cordón Caulle have evolved through

545 a series of studies since the 2011-2012 eruption. Castro et al. (2013) described how magma delivery via

$\$ 46$ a dike could have explained different ascent paths for explosively and effusively erupted magma. This

$\$ 47$ interpretation remains valid, but the extent and complexity of magma recharge and withdrawal at

$\$ 48$ Cordón Caulle was subsequently made clearer by analyses of edifice deformation (Jay et al. 2014;

549 Delgado et al. 2016). Schipper et al. (2013) used observations of waning hybrid activity and textures of

550 ash produced during the observed period and two bombs assumed to have been produced during

551 Vulcanian blasts to describe Cordón Caulle's shallow vent as an outlet primarily choked by lava-forming

552 magma that was crosscut by a branching network of permeable degassing structures that enabled gas

553 fluxing from depth to be maintained. Their interpretations also remain valid, but lacking access to the

554 full bomb field, they underestimated the degree to which the shallow conduit was filled with

555 fragmented material rather than coherent melt. Paisley et al. (2019b) then presented a more complex

556 vision of the Cordón Caulle conduit, including the recognition that repeated in-conduit fracturing was

557 pervasive, and important to producing the breccia bombs that were part of their analytical sample suite.

558 Here, our new examination of composite bombs shows that subsurface, multi-generational 
fragmentation and sintering characterized the dynamics within the shallow conduit during the explosive-effusive transition at Cordón Caulle.

Clastic products dominated the conduit at Cordón Caulle in the days immediately preceding the emergence of lava (and have been recognized at other similar volcanoes; Adams et al. 2006), and permeability of this evolving composite material was controlled by viscous sintering. From a product perspective, there is significant textural similarity between clasts and matrix within the Cordón Caulle composite bombs and tuffisites from other volcanoes (e.g., Stasiuk et al. 1996; Tuffen and Dingwell 2005; Saubin et al. 2016). From a process perspective, tuffisite formation has been described as: (1) fragmentation and deposition of fragmental material; (2) sintering and magma backfilling; and (3) excavation and outgassing (Kendrick et al. 2016). The representative length scales over which these processes occur is the only fundamental difference between tuffisite veins and the conduit that was disrupted to produce the composite bombs at Cordón Caulle. Further, the recent study of Kolzenburg et al. (2019) treats edifice-penetrating tuffisite veins and pyroclast-filled conduits as fundamentally identical, although with different sizes and geometries. Their model showed rapid conductive cooling in tuffisites to lock-in high vein permeability, whereas slow cooling in cylindrical conduits creates a wide and efficient welding window that rapidly destroys original porosity, permeability, and outgassing potential. The Cordón Caulle composite bombs provide a robust example of this fundamental conduittuffisite equivalency.

\section{Conclusions}

We have investigated the textures of composite bombs ejected in the lead-up to the explosive-effusive transition at Cordón Caulle volcano (2011-2012). We find evidence that fine ash was continuously generated in the sub-surface throughout the eruption. The finely fragmented subterranean granular suspension was ideally suited to in-conduit viscous sintering that ultimately extinguished explosivity. Therefore, the appearance of lava at Cordón Caulle - and hence the onset of the explosive-effusive transition - may have depended more on rates of melt fracture and sintering, rather than on the generation of permeable outgassing pathways in a coherent, vesiculating melt body. We conclude that in order to accurately capture the controls on explosive-effusive transitions that are critical to mitigating the hazards from silicic eruptions, new models should incorporate clastogenic (sintering) processes of textural evolution into classical visions of magmatic textural evolution. Furthermore, we see silicic conduits and much-studied tuffisite veins to be phenomenologically identical, differing only in scale.

\section{$\underline{6 \text { Acknowledgements }}$}

CIS acknowledges support from a Faculty Strategic Research Grant from VUW. BMK, RHF, ER, LNS and GS were supported by the Royal Society Te Apārangi Marsden project "Shaking magma to trigger volcanic eruptions". RHF was additionally supported by a Ngāi Tahu Research Centre Doctoral $\underline{\text { Scholarship, Te Punenga Grant, and Mason Trust Grant. RP was supported by travel and research grants }}$ 
595 from McGill University. HT was supported by Royal Society University Research Fellowship UF140716.

596 Acccess to the Australian Synchrotron was granted by ANSTO (M7045, M9095, M11725) and the New

597 Zealand Synchrotron Group.

\section{References}

600 Adams NK, Houghton BF, Fagents SA, Hildreth W (2006) The transition from explosive to effusive 601 eruptive regime: The example of the 1912 Novarupta eruption, Alaska. Geol Soc Am Bull 118:620-634. 602 doi:10.1130/B25768.1

603 Alidibirov M, Dingwell DB (2000) Three fragmentation mechanisms for highly viscous magma under 604 rapid decompression. J Volcanol Geotherm Res 100:413-421.

605 Alloway BV, Pearce NJG, Villarosa G, Outes V, Moreno PI (2015) Multiple melt bodies fed the AD 2011 606 eruption of Puyehue-Cordón Caulle, Chile. Sci Reps 5:17589. doi:10.1038/srep17589

607 Browning J, Tuffen H, James MR, Owen J, Castro JM, Halliwell S, Wehbe K (2020) Post-fragmentation 608 vesiculation timescales in hydrous rhyolitic bombs from Chaitén volcano. J S Am Earth Sci 104:102807. 609 doi:10.1016/j.jsames.2020.102807

610 Cabrera A, Weinberg RF, Wright HMN (2015) Magma fracturing and degassing associated with obsidian 611 formation: The explosive-effusive transition. J Volcanol Geotherm Res. doi:10.1016/j.jvolgeores.2014.12.014

Cabrera A, Weinberg RF, Wright HMN, Zlotnik S, Cas RAF (2011) Melt fracturing and healing: A mechanism for degassing of silicic obsidian. Geology 39:67-70. doi:10.1130/G31355.1

Cashman KV, Mangan MT (1994) Physical aspects of magmatic degassing; II, Constraints on vesiculation processes from textural studies of eruptive products. In: Carroll MR, et al. (eds) Volatiles in magmas, Reviews in Mineralogy, $\mathrm{p}^{\wedge} \mathrm{pp}$ 447-478

Cashman KV, Sparks RSJ (2013) How volcanoes work: A 25 year perspective. Geol Soc Am Bull 125:643663. doi:10.1130/B30720.1

Cassidy M, Manga M, Cashman KV, Bachmann O (2018) Controls on explosive-effusive volcanic eruption styles. Nature Comms 9:2893. doi:10.1038/s41467-018-05293-3

Castro JM, Bindeman IN, Tuffen H, Schipper Cl (2014) Explosive origin of silicic lava: Textural and $8 D-$ $\mathrm{H} 2 \mathrm{O}$ evidence for pyroclastic degassing during rhyolite effusion. Earth Planet Sci Lett 405:52-61. doi:10.1016/j.epsl.2014.08.012

Castro JM, Cordonnier B, Schipper Cl, Tuffen H, Baumann T, Feisel Y (2016) Rapid laccolith intrusion driven by explosive volcanic eruption. Nature Comms 7:13585. doi:10.1038/ncomms13585

Castro JM, Cordonnier B, Tuffen H, Tobin MJ, Puskar L, Martin MC, Bechtel HA (2012) The role of meltfracture degassing in defusing explosive rhyolite eruptions at volcán Chaitén. Earth Planet Sci Lett 333334:63-69. doi:10.1016/j.epsl.2012.04.024

Castro JM, Gardner JE (2008) Did magma ascent rate control the explosive-effusive tranisiton at the Inyo volcanic chain, California? Geology 36:279-282. doi:10.1130/G24453A.1

Castro JM, Schipper Cl, Amigo A, Silva Parejas C, Mueller S, Jacob D, Militzer AS (2013) Storage and eruption of near-liquidus rhyolite magma at Cordón Caulle, Chile. Bull Volcanol 75:702. doi:10.1007/s00445-013-0702-9

Collinson ASD, Neuberg JW (2012) Gas storage, transport and pressure changes in an evolving permeable volcanic edifice. J Volcanol Geotherm Res 243-244:1-13. doi:10.1016/j.jvolgeores.2012.06.027

Degruyter W, Bachmann O, Burgisser A, Manga M (2012) The effects of outgassing on the transition between effusive and explosive silicic eruptions. Earth Planet Sci Lett 349-350:161-170.

Degruyter W, Burgisser A, Bachmann O, Malaspinas O (2010) Synchotron X-ray microtomography and lattice Boltzmann simulations of gas flow through volcanic pumices. Geosphere 6:470-481. doi:10.1130/GES00555.1

645

Delgado F (2020) Rhyolitic volcano dynamics in the Southern Andes: Contributions from 17 years of InSAR observations at Cordón Caulle from 2003 to 2020. J S Am Earth Sci 102841. doi:10.1016/j.jsames.2020.102841 
Delgado F, Pritchard ME, Basualto D, Lazo J, Córdova L, Lara LE (2016) Rapid reinflation following the 2011- 2012 rhyodacite eruption at Cordón Caulle volcano (Southern Andes) imaged by InSAR: Evidence for magma reservoir refill. Geophys Res Lett 43:9552-9562. doi:10.1002/ 2016GL070066

Delle Donna D, Harris AJL, Ripepe M, Wright R (2010) Earthquake-induced thermal anomalies at active volcanoes. Geology 38:771-774. doi:10.1130/G30984.1

Dufek J, Manga M, Patel A (2012) Granular disruption during explosive volcanic eruptions. Nature Geosci 5:561-564. doi:10.1038/NGEO1524

Eichelberger JC (1995) Silicic Volcanism: Ascent of viscous magmas from crustal reservoirs. Annu Rev Earth Planet Sci 23:41-63.

Eichelberger JC, Carrigan CR, Westrich HR, Price RH (1986) Non-explosive silicic volcanism. Nature 323:598-602. doi:10.1038/323598a0

Eichelberger JC, Westrich HR (1981) Magmatic volatiles in explosive rhyolitic eruptions. Geophys Res Lett 8:757-760. doi:10.1029/GL008i007p00757

Elissondo M, Baumann V, Bonadonna C, Pistolesi M, Cioni R, Bertagnini A, Biass S, Herrero J-C, Gonzales R (2016) Chronology and impact of the 2011 Cordón Caulle eruption, Chile. Nat Hazards Earth Syst Sci 16:675-704. doi:10.5194/nhess-16-675-2016

Farquharson JI, Wadsworth FB, Heap MJ, Baud P (2017) Time-dependent permeability evolution in compacting volcanic fracture systems and implications for gas overpressure. J Volcanol Geotherm Res 339:81-97. doi:10.1016/j.jvolgeores.2017.04.025

Fitzgerald RH, Tsunematsu K, Kennedy BM, Breard ECP, Lube G, Wilson TM, Jolly AD, Pawson J, Rosenberg MD, Cronin SJ (2014) The application of a calibrated 3D ballistic trajectory model to ballistic hazard assessments at Upper Te Maari, Tongariro. J Volcanol Geotherm Res 286:248-262. doi:10.1016/j.jvolgeores.2014.04.006

Forte P, Castro JM (2019) H2O-content and temperature limit the explosive potential of rhyolite magma during Plinian eruptions. Earth Planet Sci Lett 506:157-167. doi:10.1016/j.epsl.2018.10.041

Gardner JE, Llewellin EW, Watkins JM, Befus KS (2017) Formation of obsidian pyroclasts by sintering of ash particles in the volcanic conduit. Earth Planet Sci Lett 459:252-263. doi:10.1016/j.epsl.2016.11.037 Gardner JE, Wadsworth FB, Llewellin EW, Watkins JM, Coumans JP (2018) Experimental sintering of ash at conduit conditions and implications for the longevity of tuffisites. Bull Volcanol 80:23. doi:10.1007/s00445-018-1202-8

Gardner JE, Wadsworth FB, Llewellin EW, Watkins JM, Coumans JP (2019) Experimental constraints on the textures and origin of obsidian pyroclasts. Bull Voclanol 81:12. doi:10.1007/s00445-019-1283-z

Gerlach DC, Frey FA, Moreno-Roa H, Lopez-Escobar L (1988) Recent volcanism in the Puyehue-Cordón Caulle region, southern Andes, Chile (40.5o S): Petrogenesis of evolved lavas. J Petrol 29:333-382.

Giachetti T, Hudak MR, Shea T, Bindeman IN, Hoxsie EC (2020) D/H ratios and H2O contents record degassing and rehydration history of rhyolitic magma and pyroclasts. Earth Planet Sci Lett 530:115909. doi:10.1016/j.epsl.2019.115909

Giordano D, Russell JK, Dingwell DB (2008) Viscosity of magmatic liquids: A model. Earth Planet Sci Lett 271:123-134. doi:10.1016/j.epsl.2008.03.038

Gonnermann HM, Manga M (2003) Explosive volcanism may not be an inevitable consequence of magma fragmentation. Nature 426:432-435.

Heap MJ, Tuffen H, Wadsworth FB, Reuschlé T, Castro JM, Schipper Cl (2019) The permeability evolution of tuffisites and implications for outgassing through dense rhyolitic magma. J Geophys Res Solid Earth 124:8281-8299. doi:10.1029/2018JB017035

Isgett SJ, Houghton BF, Fagents SA, Biass S, Burgisser A, Arbaret L (2017) Eruptive and shallow conduit dynamics during Vulcanian explosions: insights from the Episode IV block field of the 1912 eruption of Novarupta, Alaska. Bull Volcanol 79:58. doi:10.1007/s00445-017-1138-4

Jay J, Costa F, Pritchard M, Lara LE, Singer BS, Herrin J (2014) Locating magma reservoirs using InSAR and petrology before and during the 2011-2012 Cordón Caulle silicic eruption. Earth Planet Sci Lett 395:254-266. doi:10.1016/j.epsl.2014.03.046

Kendrick JE, Lavallée Y, Varley N, Wadsworth FB, Lamb OD, Vasseur J (2016) Blowing Off Steam: Tuffisite Formation As a Regulator for Lava Dome Eruptions. Front Earth Sci 4:41. doi:10.3389/feart.2016.00041 Kennedy BM, Wadsworth FB, Vasseur J, Schipper Cl, Jellinek AM, von Aulock FW, Hess K-U, Russell JK, Lavallée $Y$, Nichols ARL, Dingwell DB (2016) Surface tension driven processes densify and retain permeability in magma and lava. Earth Planet Sci Lett 433:116-124. doi:10.1016/j.epsl.2015.10.031 Kolzenburg S, Heap MJ, Lavallée Y, Russell JK, Meredith PG, Dingwell DB (2012) Strength and permeability recovery of tuffisite-bearing andesites. Solid Earth 3:191-198. doi:10.5194/se-3-191-2012 
Kolzenburg S, Ryan AG, Russell JK (2019) Permeability evolution during non-isothermal compaction in volcanic conduits and tuffisite veins: Implications for pressure monitoring of volcanic edifices. Earth Planet Sci Lett 527:115783. doi:10.1016/j.epsl.2019.115783

Kueppers U, Scheu B, Spieler O, Dingwell DB (2006) Fragmentation efficiency of explosive volcanic eruption: A study of experimentally generated pyroclasts. J Volcanol Geotherm Res 153:125-135. doi:10.1016/j.jvolgeores.2005.08.006

Lara LE (2008) The 2008 eruption of the Chaitén Volcano, Chile: a preliminary report. Andean Geol 36:125-129.

Lara LE, Moreno H, Naranjo JA, Matthews S, Pérez de Arce C (2006) Magmatic evolution of the PuyehueCordón Caulle Volcanic Complex $\left(40^{\circ} \mathrm{S}\right)$, Southern Andean Volcanic Zone: From shield to unusual rhyolite fissure volcanism. J Volcanol Geotherm Res 157:343-366.

Lara LE, Naranjo JA, Moreno H (2004) Rhyodacitic fissure eruption in Southern Andes (Cordón Caulle; $40.5^{\circ} \mathrm{S}$ ) after the 1960 (Mw: 9.5) Chilean earthquake: A structural interpretation. J Volcanol Geotherm Res 138:127-138.

Limaye A (2012) Drishti: a volume exploration and presentation tool. In: Developments in X-Ray Tomography VIII.

Magnall N, James MR, Tuffen H, Vye-Brown C (2017) Emplacing a cooling-limited rhyolite lava flow: Similarities with basaltic lava flows. Front Earth Sci 5:44. doi:10.3389/feart.2017.00044

Newman S, Epstein S, Stolper EM (1988) Water, carbon dioxide, and hydrogen isotopes in glasses from the ca. 1340 A.D. eruption of the Mono Craters, California: Constraints on degassing phenomena and initial volatile content. J Volcanol Geotherm Res 35:75-96.

Nguyen CT, Gonnermann HM, Houghton BF (2014) Explosive to effusive transition during the largest volcanic eruption of the 20th

century. Geology 42:703-706. doi:10.1130/G35593.1

Paisley R, Berlo K, Ghaleb B, Tuffen H (2019a) Geochemical constraints on the role of tuffisite veins in degassing at the 2008-09 Chaitén and 2011-12 Cordón Caulle rhyolite eruptions. J Volcanol Geotherm Res 380:80-93. doi:j.jvolgeores.2019.05.013

Paisley R, Berlo K, Whattam J, Schipper Cl, Tuffen H (2019b) Degassing-induced chemical heterogeneity at the 2011-2012 Cordón Caulle eruption. Volcanica 2:211-237. doi:10.30909/vol.02.02.211237

Pallister JS, Diefenbach AK, Burton WC, Muñoz J, Griswold JP, Lara LE, Lowenstern JB, Valenzuela CE (2013) The Chaitén rhyolite lava dome - Eruption sequence, lava dome volumes, rapid effusion rates and source of the rhyolite magma. Andean Geology 40:277-294. doi:10.5027/andgeoV40n2-a0?6?

Pistolesi M, Cioni R, Bonadonna C, Elissondo M, Baumann V, Bertagnini A, Chiari L, Gonzales R, Rosi M, RFrancalanci L (2015) Complex dynamics of small-moderate volcanic events: the example of the 201112 rhyolitic Cordón Caulle eruption, Chile. Bull Volcanol 77:3. doi:10.1007/s00445-014-0898-3

Quane SL, Russell JK (2005) Ranking welding intensity in pyroclastic deposits. Bull Voclanol 67:129-143. doi:10.1007/s00445-004-0367-5

Rust AC, Cashman KV (2004) Permeability of vesicular silicic magma: inertial and hysteresis effects. Earth Planet Sci Lett 228:93-107. doi:10.1016/j.epsl.2004.09.025

Rust AC, Cashman KV, Wallace P (2004) Magma degassing buffered by vapour flow through brecciated conduit margins. Geology 32(4):349-352.

Saubin E, Tuffen H, Gurioli L, Owen J, Castro JM, Berlo K, McGowan E, Schipper Cl, Wehbe K (2016) Conduit dynamics in transitional rhyolitic activity recorded by tuffisite vein textures from the 2008-2009 Chaitén eruption. Frontiers Earth Sci Volcanol 4:59. doi:10.3389/feart.2016.00059

Sawi TM, Manga M (2018) Revisiting short-term earthquake triggered volcanism. Bull Volcanol 80:57. doi:10.1007/s00445-018-1232-2

Schipper Cl, Castro JM, Kennedy BM, Christenson BW, Aiuppa A, Alloway BV, Forte P, Seropian G, Tuffen $\mathrm{H}$ (2019) Halogen ( $\mathrm{Cl}, \mathrm{F}$ ) and sulphur release during explosive, effusive, and intrusive phases of the 2011 rhyolitic eruption at Cordón Caulle volcano (Chile). Volcanica 2:73-90. doi:10.30909/vol.02.01.7390

Schipper Cl, Castro JM, Tuffen H, James MR, How P (2013) Shallow vent architecture during hybrid explosive-effusive activity at Cordón Caulle (Chile, 2011-12): Evidence from direct observations and pyroclast textures. J Volcanol Geotherm Res 262:25-37. doi:10.1016/j.jvolgeores.2013.06.005

Schipper Cl, Castro JM, Tuffen H, Wadsworth FB, Chappell D, Pantoja AE, Simpson M, Le Ru EC (2015) Cristobalite in the 2011-12 Cordón Caulle eruption (Chile). Bull Volcanol 77:34. doi:10.1007/s00445015-0925-z 
Schipper CI, Rickard WDA, Reddy SM, Saxey DW, Castro JM, Fougerouse D, Quadir Z, Conway CE, Prior DJ, Lilly K (2020) Volcanic SiO2-Cristobalite: A natural product of chemical vapor deposition. Amer Mineral 105:510-524. doi:10.2138/am-2019-7236

Schneider CA, Rasband WS, Eliceiri KW (2012) NIH Image to ImageJ: 25 years of image analysis. Nature Methods 9:671-675.

SERNAGEOMIN/OVDAS (2011) 38.

Silva Parejas C, Lara LE, Bertin D, Amigo A, Orozco G (2012) The 2011-2012 eruption of Cordón Caulle volcano (Southern Andes): Evolution, crisis management and current hazards. EGU General Assembly Abstracts 14(EGU2012-9382-2).

Sparks RSJ (1978) The dynamics of bubble formation and growth in magmas: A review and analysis. J Volcanol Geotherm Res 3:1-37.

Spieler O, Kennedy B, Kueppers U, Dingwell DB, Scheu B, Taddeucci J (2004) The fragmentation threshold of pyroclastic rocks. Earth Planet Sci Lett 226:139-148.

Stasiuk MV, Barclay J, Carroll MR, Jaupart C, Ratté JC, Sparks RSJ, Tait SR (1996) Degassing during magma ascent in the mule creek vent (USA). Bull Volcanol 58:117-130.

Taylor BE, Eichelberger JC, Westrich HR (1983) Hydrogen isotopic evidence of rhyolitic magma degassing during shallow intrusion and eruption. Nature 306:541-545. doi:10.1038/306541a0 Tuffen H, Dingwell D (2005) Fault textures in volcanic conduits: Evidence for seismic trigger mechanisms during silicic eruptions. Bull Volcanol 67:370-387. doi:10.1007/s00445-004-0383-5

Tuffen H, Dingwell DB, Pinkerton H (2003) Repeated fracturing and healing of silicic magma generate flow banding and earthquakes? Geology 31:1089-1092.

Tuffen H, James MR, Castro JM, Schipper Cl (2013) Exceptional mobility of an advancing rhyolitic obsidian flow at Cordón Caulle volcano in Chile. Nature Comm 4:2709. doi:10.1038/ncomms3709

Tuffen H, Smith R, Sammonds PR (2008) Evidence for seismogenic fracture of silicic magma. Nature 453:511-514. doi:10.1038/nature06989

Vasseur J, Wadsworth FB, Lavallée Y, Hess K-U, Dingwell DB (2013) Volcanic sintering: Timescales of viscous densification and strength recovery. Geophys Res Lett 40:5658-5664. doi:10.1002/2013GL058105

von Aulock FW, Kennedy BM, Maksimenko A, Wadsworth FB, Lavallée Y (2017) Outgassing from open and closed magma foams. Frontiers Earth Sci Volcanol 5:46. doi:10.3389/feart.2017.00046

Wadsworth FB, Llewellin EW, Vasseur J, Gardner JE, Tuffen H (2020) Explosive-effusive volcanic eruption transitions caused by sintering. Sci Adv 6:eaba7940. doi:10.1126/sciadv.aba7940

Wadsworth FB, Vasseur J, Schauroth J, Llewellin EW, Dobson KJ, Havard T, Scheu B, von Aulock FW, Gardner JE, Dingwell DB, Hess K-U, Colombier M, Marone F, Tuffen H, Heap MJ (2019) A general model for welding of ash particles in volcanic systems validated using in situ X-ray tomography. Earth Planet Sci Lett 525:115726. doi:10.1016/j.epsl.2019.115726

Wadsworth FB, Vasseur J, Scheu B, Kendrick JE, Lavallée Y, Dingwell DB (2016) Universal scaling of fluid permeability during volcanic welding and sediment diagenesis. Geology 44:219-222. doi:10.1130/G37559.1

Wadsworth FB, Vasseur J, von Aulock FW, Hess K-U, Scheu B, Lavallée Y, Dingwell DB (2014) Nonisothermal viscous sintering of volcanic ash. J Geophys Res 119:8792-8804. doi:10.1002/2014JB011453

Wang C, Luo ZJ, Huang X (2011) Parallax correction in collocating CloudSat and Moderate Resolution Imaging Spectroradiometer (MODIS) observations: Method and application to convection study. J Geophys Res 116:D17201. doi:10.1029/2011JD016097

Whattam J (2018) Under the surface: Textural analysis of complex, multi-component Vulcanian bombs produced during the hybrid explosive-effusive phase of the 2011-2012 Cordón Caulle eruption, Chile. MSc thesis. Victoria University of Wellington, Wellington, p 152

Wright HMN, Cashman KV (2014) Compaction and gas loss in welded pyroclastic deposits as revealed by porosity, permeability, and electrical conductivity measurements of the Shevlin Park Tuff. Geol Soc Am Bull 126:234-247. doi:10.1130/B30668.1

Yamagashi H, Freebrey C (1994) Ballistic ejecta from the 1988-1989 andesitic Vulcanian eruptions of Tokachidake volcano, Hapan: morphological features and genesis. J Volcanol Geotherm Res 59:269278. doi:10.1016/0377-0273(94)90082-5

\section{Figure Captions}


814 Figure 1. Location and eruption progression. A-F. Terra/MODIS (NASA Worldview) images spanning the

815 first 16 days of the 2011-2012 Cordón Caulle eruption. Apparent shift in vent location from June 5 - 7

816 is a function of different off-nadir view angles; once corrected for parallax the vent locations are within

817 error of each other (Wang et al. 2011). Deformation centres identified in INSAR interferograms by Jay

$\$ 18$ et al. (2014). Inset to F shows location of the Puyehue Cordón Caulle Volcanic Complex (PCVCC). G.

$\$ 19$ GeoEye-1 image of multiple vents, 2 weeks after lava emergence. Inset shows location of the Puyehue-

$\$ 20$ Cordón Caulle Volcanic Complex (PCVCC).

821 Figure 2. Bomb distributions. A. Recent deposits from Cordón Caulle (Google Earth Image taken 4 Oct, 8222012 by Maxar Technologies, 2020). Red points are sampled composite bombs, dashed lines mark 823 approximate extents of "proximal" and "distal" bomb fields. Boxes show locations of images in B-C. B-

824 C. Orthographic images from a 2017 overflight of Cordón Caulle (Schipper et al., unpublished data). B. 825 The 2011-2012 vent(s), littered with dark, dense, proximal lava bombs that lack ballistic impact craters. 826 C. An ash-covered topographic high that is heavily pockmarked by ballistic impact craters. D-E. 827 Photographs of proximal bomb field (D) and typical impact crater in distal bomb field (E).

828 Figure 3. Cordón Caulle bombs. A. Proximal lava bombs/blocks. B. Proximal obsidian bomb with 829 localized expansion along some flow bands. C-D. Breadcrusted composite bombs. Inset to (D) shows 830 cavity at the bomb's centre indicating en masse expansion regardless of multicomponent structure. E-

$\$ 31$ F. Low-density composite bombs primarily composed of flattened pumice in an oxidized matrix. The $\$ 32$ bombs shown in (E) was selected for high-resolution CT analysis. G-H. High-density composite bombs. 833 Similar in overall structure to (D-F), but with a higher proportion of dense clasts. I. Composite bomb in 834 which matrix volumetrically dominates over clasts. J. Obsidian bomb lacking any obvious matrix, but 835 still composite due to containing pumice clasts.

836 Figure 4. Textures of composite bombs. A. Breadcrusted composite bomb from which all images were 837 collected. B. Flatbed scan of thin section. Large brown vesicular clast in the centre is mafic. C-H. BSE 838 images from the thin section in (B). Red arrows indicate some of the mafic particles, which appear 839 lighter than rhyolite in BSE images. Orange dashed lines indicate boundaries between domains where 840 identifiable. C. Obsidian with "homogeneous" region and "clastogenic" region that contains mafic 841 domains and particle outlines that reveal a clastic origin. Interface is expanded in inset frame. D. 842 Pumices that have isotropically foamed in situ, bound to obsidian and other clasts by sintered matrix.

843 E. Thick matrix domain separating borderless and foamed pumice clasts. Note that the matrix maintains 844 significant porosity despite constituent particles being flattened parallel to the long axis of the domain 845 itself. F. Two foamed pumice clasts bound by mafic-bearing matrix material. Note that vesicles in the 846 right-hand pumice are flattened against the matrix domain. G. Low-porosity matrix. Most of the pore 847 space is adjacent to mafic particles. H. Matrix that has vesiculated in situ after binding together 848 crystalline lithic and borderless pumice clasts. The matrix shown in E-H roughly delineate a progression 849 in textural evolution, first on a sintering path of declining porosity from $E$ to $G$, and then a path of $\$ 50$ vesiculation from $\mathrm{G}$ to $\mathrm{H}$. 
851 Figure 5. Histogram of particle sizes (5 $\mu \mathrm{m}$ bins) within sintering and/or clastogenic domains. 2D Particle

$\$ 52$ diameters $(n=1525)$ were measured on 61 BSE images from nine different composite bombs. The

853 measured particles are dominantly from within matrix domains, but identifiable particles from within

854 clastogenic obsidian were also included in the count where possible (e.g., mafic particles in Fig. 4B). The

855 size range of $10-20 \mu \mathrm{m}$ accounts for $45 \%$ of particles.

856 Figure 65 . CT investigation of composite bombs. A-B. 3D renderings of low-resolution CT scans of clast-

857 dominated (A) and matrix-dominated (B) composite bombs. C. High-resolution 3D rendering of

858 composite bomb material, capturing a wide range of different components. D. Example subvolumes

859 isolated from (C), upon which Lattice Boltzmann permeability simulations were performed. Lower case

860 Roman numerals link these specific volumes to their porosities and permeabilities in (E) E. Porosity-

861 permeability plot for composite bomb components, against relationships for sintering of monodisperse

862 rhyolite particles (Wadsworth et al. 2016) and natural welded tuffs (Wright and Cashman 2014).

863 Figure 6 7 . A qualitative magmatic-clastogenic textural evolution cycle in porosity $(\varphi)$ - permeability (k)

$\$ 64$ space. Figure is based on the porosity-permeability-hysteresis loop described by (Rust and Cashman

865 2004) and illustrated by (Cashman and Sparks 2013). Processes are marked within axes, and products

866 are indicated outside axes. The magmatic and clastogenic cycles begin (at $t_{0}$ ) from a coherent bubble-

867 free melt and a fragmented granular suspension, respectively. The colours of arrows and text indicate

868 which processes and products are unique to each cycle or common to both. Note that all textures

869 observed in Cordón Caulle composite bombs can be achieved by clastogenic processes, but not all can

870 be linked to magmatic processes. The figure is necessarily qualitative because key limits such as the

871 percolation threshold $\left(\phi_{\mathrm{c}}\right)$ are vastly different in magmatic $\left(0.2 \leq \phi_{\mathrm{c}} \leq 0.7\right)$ and clastogenic $\left(\phi_{\mathrm{c}} \approx 0.03\right)$

872 systems (Wadsworth et al. 2016 and references therein).

$\$ 73$ Figure 8Figure 7. Schematic portrayal of the evolution of clastogenic processes in the first 10 days of \$74 the 2011-2012 Cordón Caulle eruption. Images are roughly to scale in the horizontal, based on the

$\$ 75$ surface expressions of the laccolith and vent (e.g., as in Fig. 2A). Vertical is not to scale. 


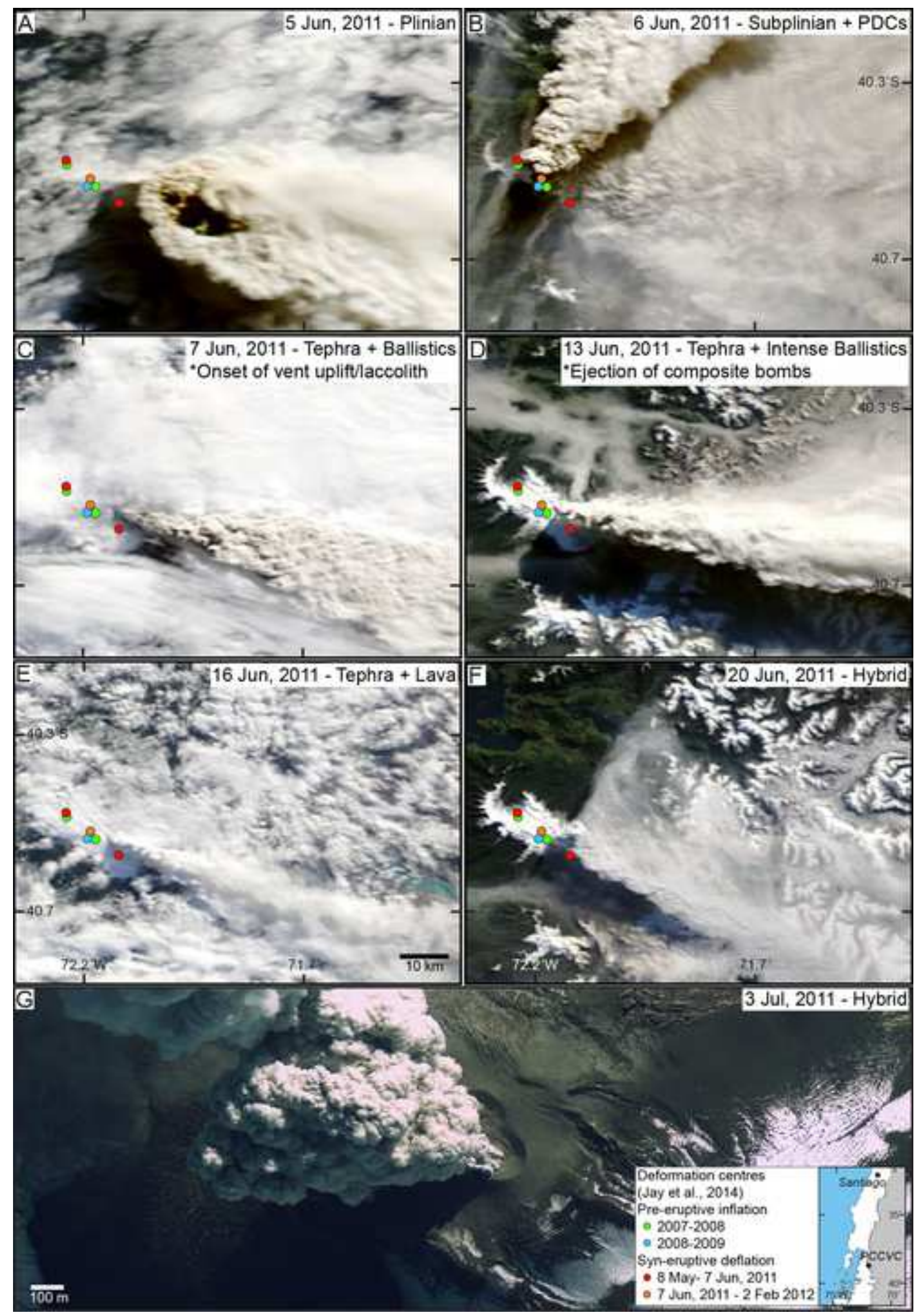




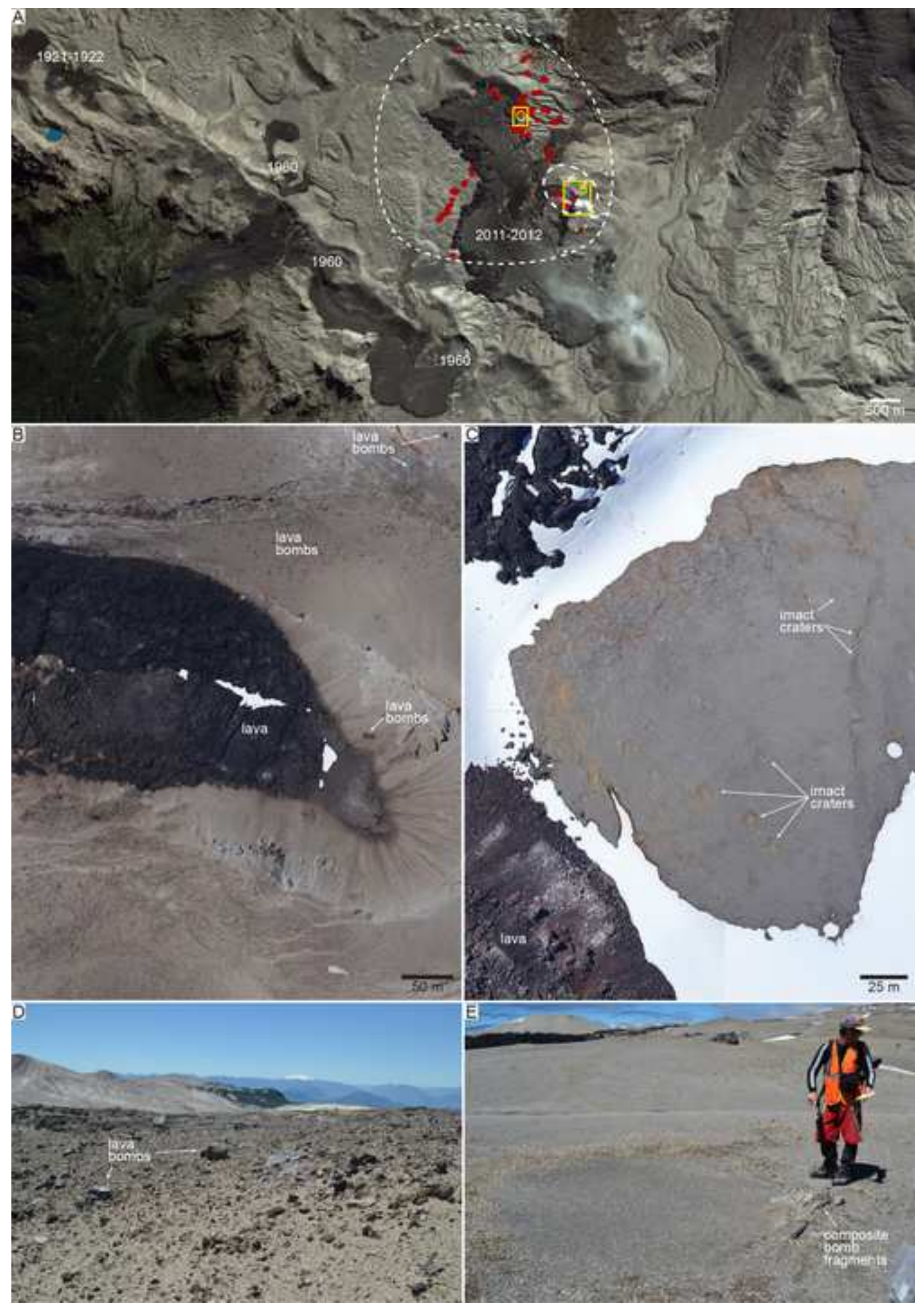


Proximal Homogeneous Bombs

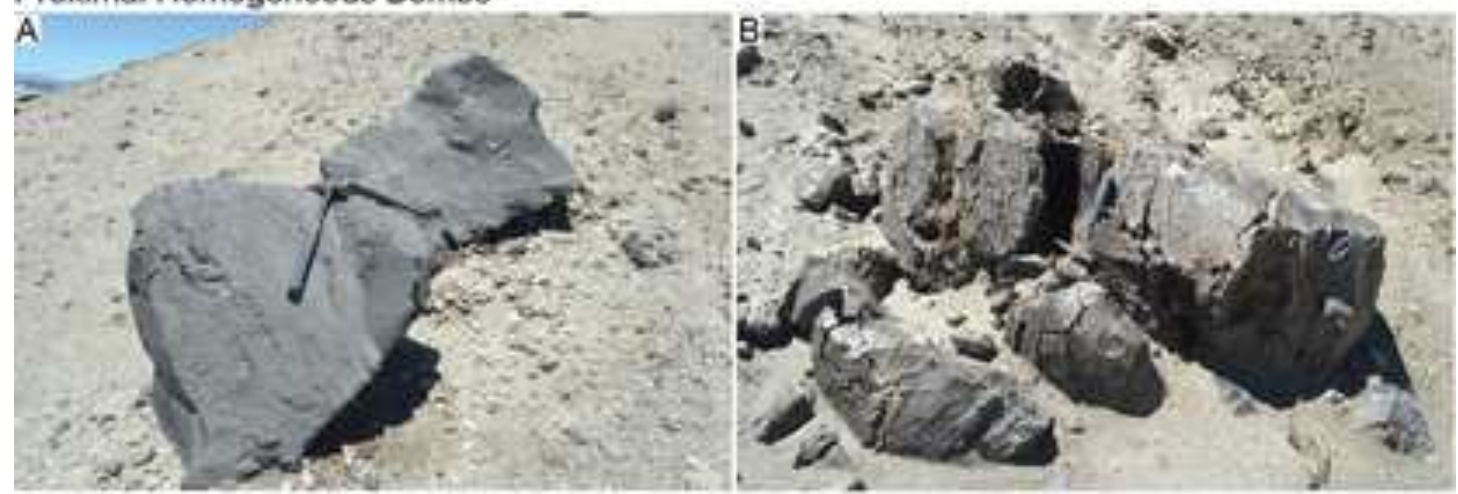

Distal Composite Bombs
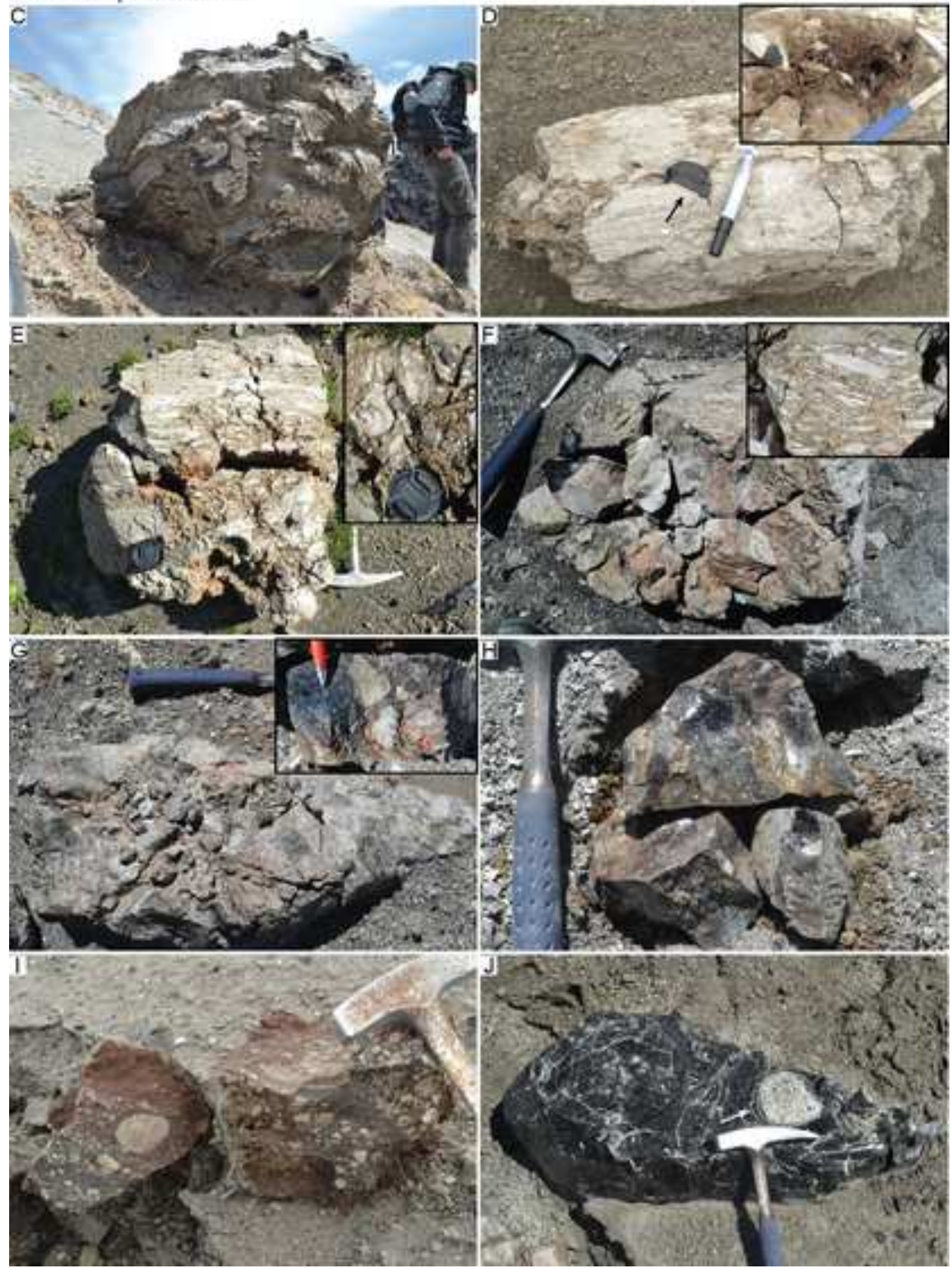


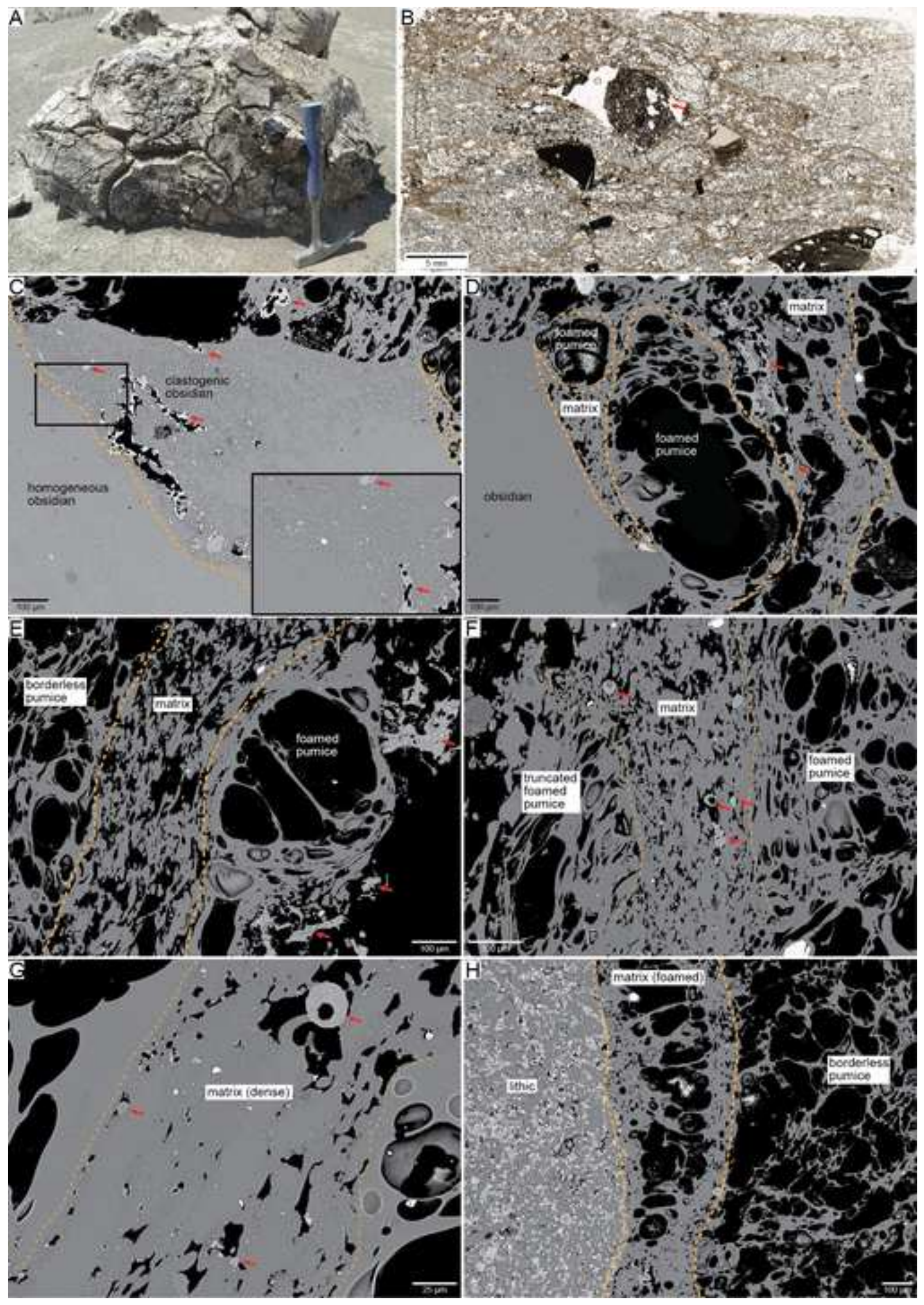


Click here to access/download;Figure;Schipper et al. R1-Fig.5.jpg $\underline{\underline{ }}$

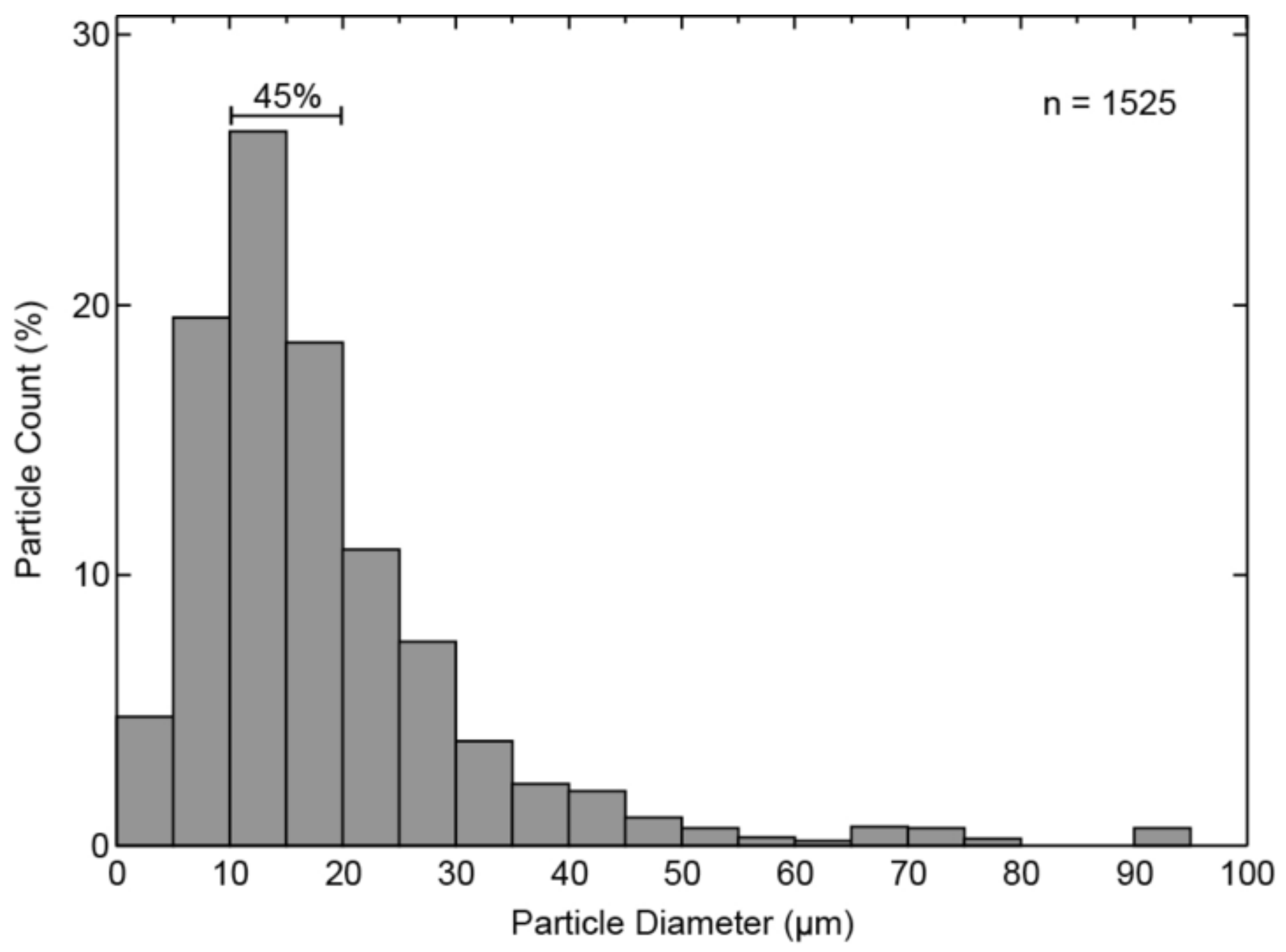



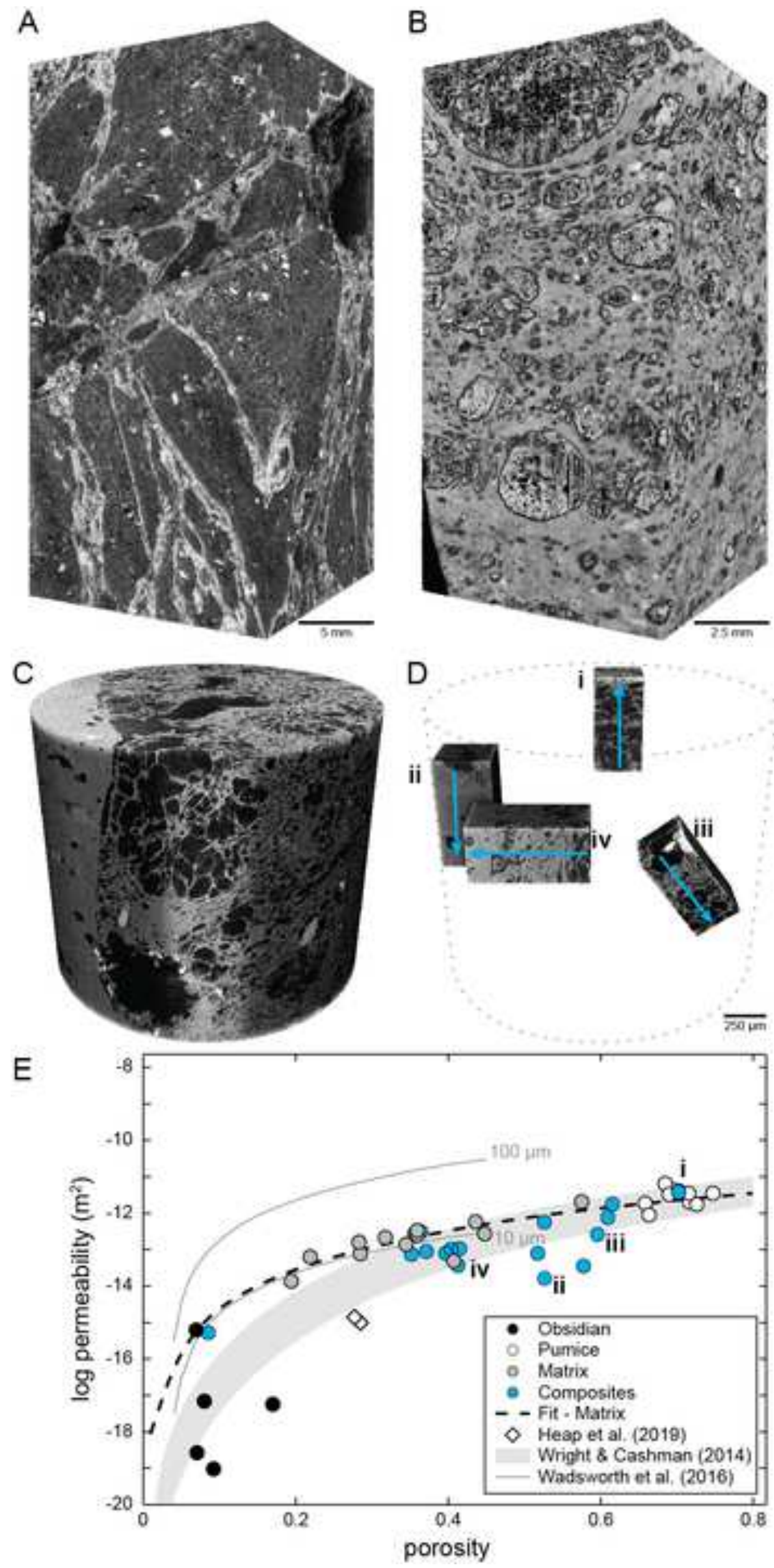


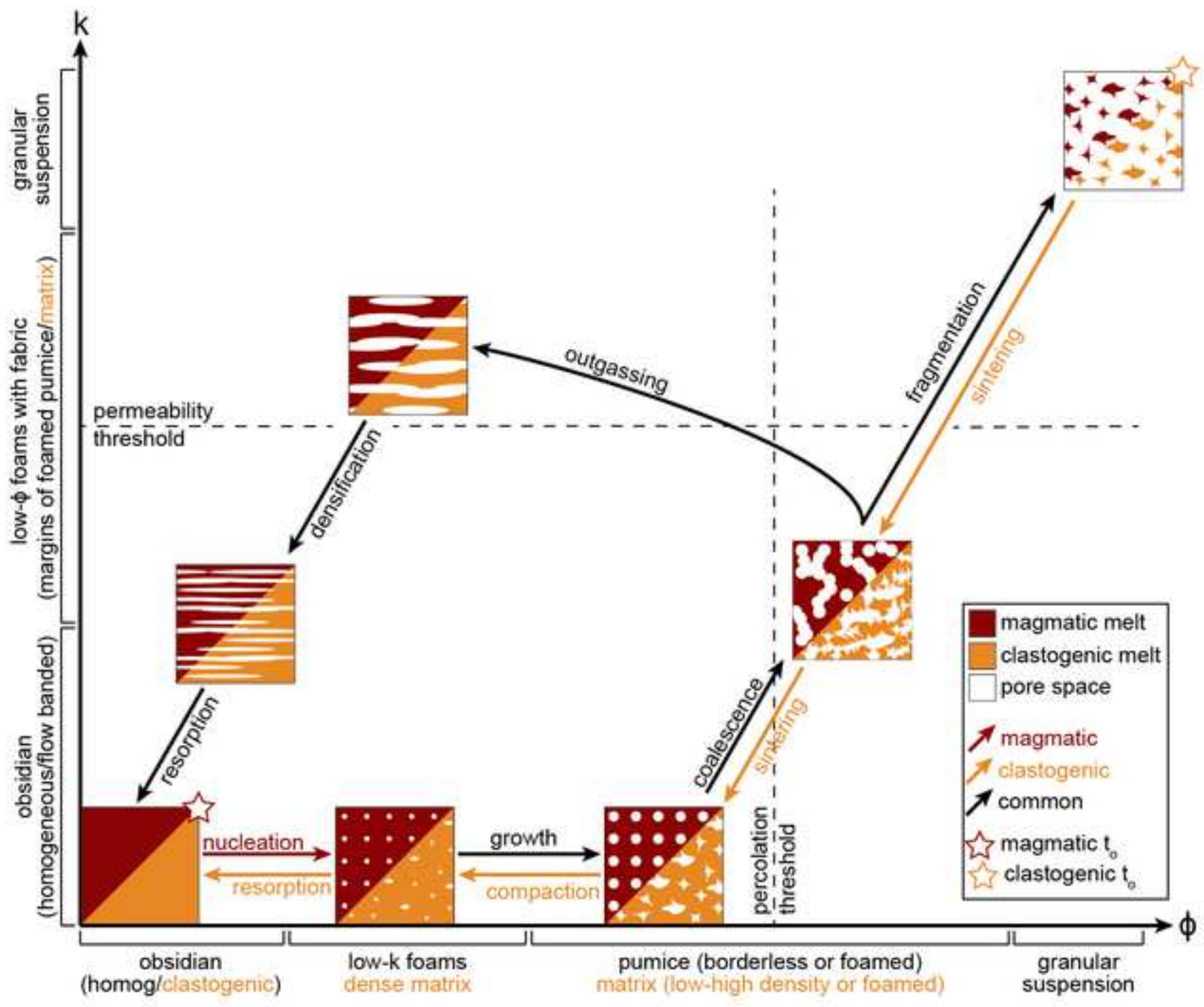



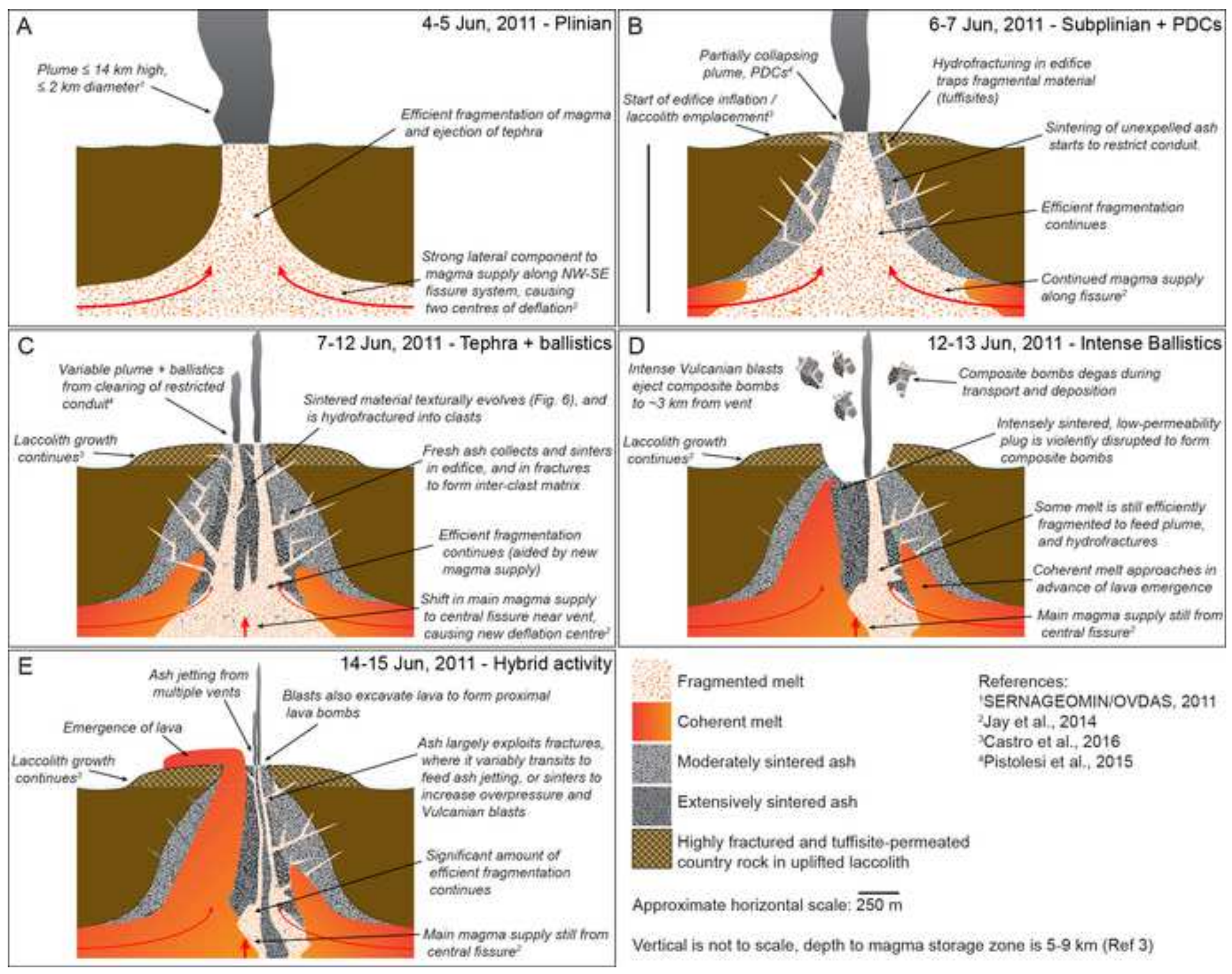

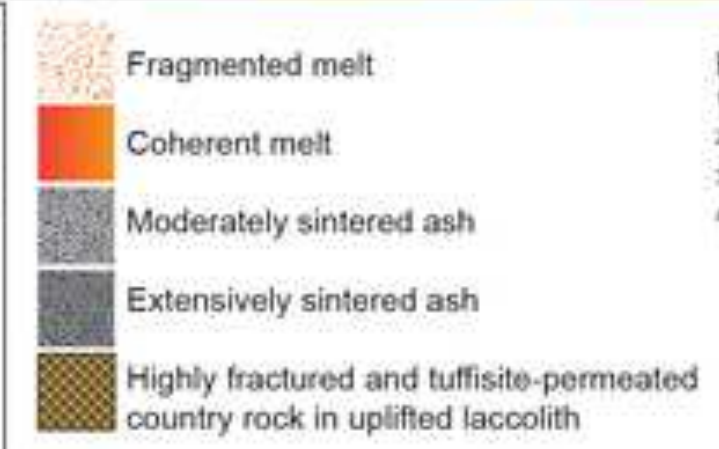

References:

SERNAGEOMINIOVDAS, 2011

2Jay et al, 2014

Castro et al., 2016

"Pistolesi et ai., 2015

Approximate horizontal scale: $\overline{250 \mathrm{~m}}$

Vertical is not to scale, depth to magma storage zone is $5.9 \mathrm{~km}$ (Ref 3 ) 


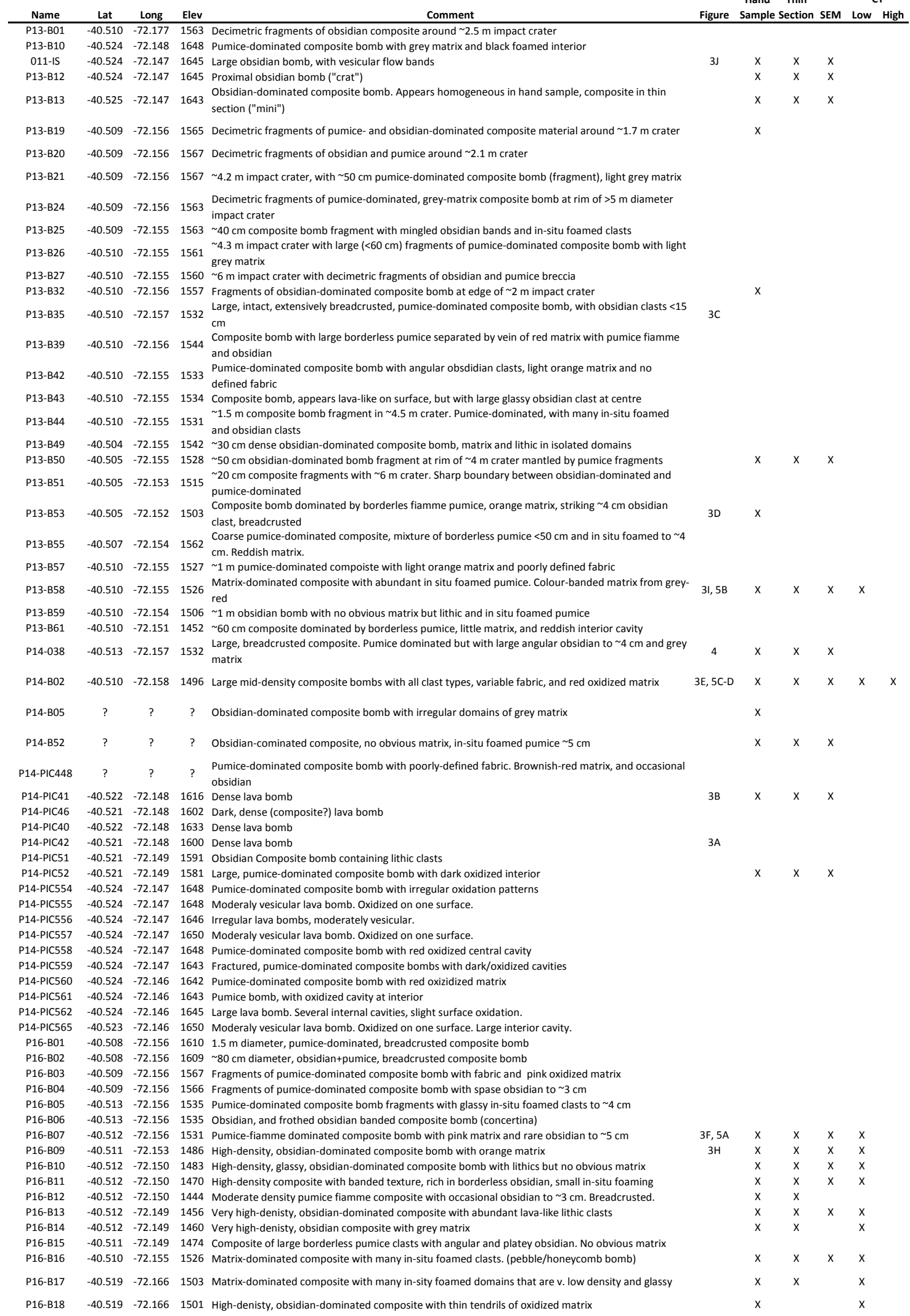




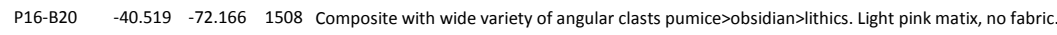

P16-B21 -40.520 -72.166 1502 Variably-foamed, banded, obsidian+foam composite.

\begin{tabular}{llll} 
P16-B22 & -40.521 & -72.168 & 1508 \\
\hline
\end{tabular}

$\begin{array}{llll}\mathrm{X} & \mathrm{x} & \mathrm{x} & \mathrm{x} \\ \mathrm{x} & \mathrm{x} & \mathrm{x} & \mathrm{x}\end{array}$

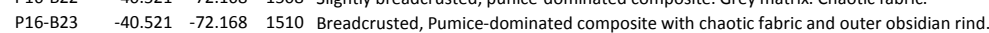

